\title{
School of Economics
}

\section{Crowdfunding and Social Capital}

\author{
A Systematic Literature Review
}

\author{
Wanxiang Cai \\ Friedemann Polzin \\ Erik Stam
}


Utrecht University School of Economics (U.S.E.) is part of the faculty of Law, Economics and Governance at Utrecht University. The U.S.E. Research Institute focuses on high quality research in economics and business, with special attention to a multidisciplinary approach. In the working papers series the U.S.E. Research Institute publishes preliminary results of ongoing research for early dissemination, to enhance discussion with the academic community and with society at large.

The research findings reported in this paper are the result of the independent research of the author(s) and do not necessarily reflect the position of U.S.E. or Utrecht University in general. 


\title{
School of Economics
}

U.S.E. Research Institute

Working Paper Series 19-05

\section{Crowdfunding and Social Capital: A Systematic Literature Review}

\author{
Wanxiang Cai \\ Friedemann Polzin \\ Erik Stam
}

Utrecht School of Economics Utrecht University

February 2019

\begin{abstract}
Crowdfunding has been rising rapidly as a new entrepreneurial finance channel. Research on crowdfunding has also been on the rise recently, with social capital theory as one of the most promising theories for understanding crowdfunding. Research on the relationship between social capital and crowdfunding includes many different perspectives and uses a large variety of classifications of social capital. This paper aims to provide a comprehensive review of how social capital affects crowdfunding. This paper classifies social capital into structural, relational and cognitive dimensions and describes elements of each dimension of social capital based on social capital research. Based on this classification, this paper expands the scope of social capital crowdfunding research to studies involving facets of social capital such as trust and identity. This paper conceptually analyses how each facet of social capital affects crowdfunding. Based on this review of research, a synthetic model is built to explain how different facets of social capital develop in virtual communities and how they interplay with each other and finally affect crowdfunding success. We finish this paper with directions for future research.
\end{abstract}

Keywords: Social Capital; Crowdfunding; Virtual Community; Systematic Literature Review

JEL classification: G23; L26

Comments welcomed to: w.cai@uu.nl 


\section{Introduction}

Crowdfunding is a new and rapidly growing phenomenon in entrepreneurship, allowing project owners to request funding from a potentially large pool of funders. Mollick (2014, p. 2) defines crowdfunding as 'the efforts by entrepreneurial individuals and groups - cultural, social, and forprofit - to fund their ventures by drawing on relatively small contributions from a relatively large number of individuals using the internet, without standard financial intermediaries'.

Scholars classify crowdfunding models according to the 'reward' for investors into a donation, rewards-based, lending and equity model (Belleflamme et al. 2014). Donation crowdfunding follows a patronage model, in which funders function as philanthropists (Mollick 2014). In reward crowdfunding, investors receive perks such as advanced versions of a product. Most investors in reward crowdfunding do not expect financial returns (Belleflamme et al., 2015). In debt-based crowdfunding or lending crowdfunding, investors offer microloans to entrepreneurs, receiving a fixed interest rate (Bouncken et al. 2015). Finally, in equity crowdfunding campaigns, entrepreneurs issue specified amounts of equity or bond-like shares of their ventures (Ahlers et al. 2015).

Although crowdfunding is a relatively new topic in entrepreneurship research, a few literature reviews have been published trying to depict the landscape of crowdfunding research and identify future research directions (Block et al. 2018; Drover et al. 2017; Mochkabadi and Volkmann 2018; Short et al. 2017). These reviews have their own specific focus. For example, some focus on one type of crowdfunding (Mochkabadi and Volkmann, 2018) or collect papers only from leading management and entrepreneurship journals (Short et al. 2017). This paper provides a more balanced approach between the scope and depth when collecting the literature and answers major questions concerning all types of crowdfunding. 
Social capital theory has been extensively applied in crowdfunding research, and entrepreneurs' social capital is one of the main determinants of crowdfunding success. Gerber et al. (2012) suggested that one factor motivating people to fund a project through crowdfunding is the social interactions which can be realised through crowdfunding platforms (e.g., strengthening commitment to an idea through feedback and feelings of connectedness to a community with similar interests and ideals). 'Interactions', 'connectedness' and 'similar interest' all belong to the concept of social capital. Meanwhile, fundraisers rely on their social capital to support their campaigns (Agrawal et al. 2015; Colombo et al. 2015; Vismara 2016a). Thus, we want to explore the relationship between social capital and crowdfunding performance

Social capital generally represents the value embedded in the social relationships of individuals or collectives (Payne et al. 2011). Entrepreneurship scholars consider social capital a valuable resource since it helps entrepreneurs to overcome information asymmetry, share knowledge and identify opportunities. Specifically, in the field of entrepreneurial finance, research has indicated that offline investments in early-stage ventures are likely to be local because trust and reputation play an important role in finance, especially when regulations and oversight are absent (Agrawal et al. 2015). Unlike offline investment in which trust and reputation are built through interpersonal interactions, the greater distance between founders and advocates in online investments makes it difficult for founders to build relationships with potential investors. Therefore, in the crowdfunding domain, we still need to gain a deeper understanding of how project creators can benefit from social capital (McKenny et al. 2017; Skirnevskiy et al. 2017).

Scholars have studied the role of social capital from different perspectives, including signalling theory (Ahlers et al., 2015), social network theory (Vismara 2016a; Skirnevskiy et al. 2017), social identity theory (Kromidha and Robson 2016), institutional perspectives (Kshetri 2015) and 
psychological capital theory (Anglin et al. 2018). Scholars have also used different classifications, including structural, relational, and cognitive dimensions (Zheng et al. 2014); individual and territorial dimensions (Giudici et al. 2013); and internal and external dimensions (Colombo et al. 2015, Butticè et al. 2017). Meanwhile, crowdfunding research focussing on social capital remains fragmented: Some crowdfunding research only studies certain facets or dimensions of social capital, without covering all dimensions of social capital. Moreover, research only focusses on the role of social capital at certain stages of crowdfunding campaigns, for example, in the early stage (Colombo et al. 2015), making it difficult to capture the effect of social capital on crowdfunding success over time. Finally, the interplay of different dimensions of social capital are neglected in most papers. In fact, different dimensions of social capital do not work separately to affect information sharing and cooperation in the community (Inkpen and Tsang 2005). Therefore, this paper not only analyses how different dimensions of social capital affect crowdfunding performance, but also introduces the concept of virtual community, an online social network in which community members interact with each other, in a conceptual model to explain how virtual communities affect the formation and evolution of social capital, thereby influencing crowdfunding campaign performance over time.

The remainder of this review is structured as follows. First, it describes the different dimensions of social capital and the facets of each dimension and explains how the literature for this review has been collected. Then it summarises how each facet of structural, relational and cognitive social capital affects crowdfunding. Next, it synthesises a theoretical model to explain how social capital affects crowdfunding performance. Finally, it summarises the researchers' conclusions and suggested future directions for research on how social capital affects crowdfunding performance. 


\section{Methodology}

We have used procedures to collect literature in a transparent and reproducible way (Fisch and Block 2018). Previous research on the relationship between social capital and crowdfunding remains fragmentary, partly due to the inconsistency in the definition of social capital. Therefore, we identified a classification of social capital first. Then we follow the procedures of Nguyen et al. (2018) to locate, select and evaluate studies. We searched the combination of each facet of social capital and crowdfunding in the Web of Science and Google Scholar to collect research on the relationship between social capital and crowdfunding. Following some criteria (see below), we deleted irrelevant studies (e.g., those from other fields and those which did not deal with social capital in their model or hypotheses), arriving at the final set of papers for the literature review.

\section{The classification of social capital}

Social capital is a multidimensional concept. Nahapiet and Ghoshal (1998) divided social capital into three dimensions: structural, relational and cognitive. The seminal work by Nahapiet and Ghoshal (1998) has provided the theoretical foundation for influential research on social capital (e.g., Tsai and Ghoshal, 1998; Wasko and Faraj, 2005; Chow and Chan, 2008).

Structural social capital refers to the overall pattern of connections between individuals embedded in social networks, relational social capital describes the kinds of personal relationships which individuals develop through interaction with each other, and cognitive social capital refers to the resources which provide shared interpretations, representation and meaning in the group (Nahapiet and Ghoshal, 1998). We collected the literature following this classification and described the facets of each dimension (see Table 1). 
Table 1. Facets of each dimension of social capital

\begin{tabular}{|c|c|c|c|}
\hline Dimensions & Facets & Description & Source \\
\hline \multirow{3}{*}{$\begin{array}{l}\text { Structural } \\
\text { social } \\
\text { capital }\end{array}$} & $\begin{array}{l}\text { Social network } \\
\text { ties }\end{array}$ & $\begin{array}{l}\text { Social network ties } \\
\text { provide access to } \\
\text { resources. }\end{array}$ & $\begin{array}{l}\text { Nahapiet and } \\
\text { Ghoshal (1998); } \\
\text { Huysman and de } \\
\text { Wit (2004); } \\
\text { Zheng et al., } \\
\text { 2014) }\end{array}$ \\
\hline & $\begin{array}{l}\text { Social network } \\
\text { configuration }\end{array}$ & $\begin{array}{l}\text { The network } \\
\text { configuration } \\
\text { determines the pattern } \\
\text { of linkages among the } \\
\text { individuals in the } \\
\text { network. }\end{array}$ & $\begin{array}{l}\text { Nahapiet and } \\
\text { Ghoshal (1998); } \\
\text { Inkpen and Tsang } \\
\text { (2005) }\end{array}$ \\
\hline & Organisations & $\begin{array}{l}\text { Organisations create } \\
\text { social networks, } \\
\text { establish social norms } \\
\text { and promote civic } \\
\text { engagement. }\end{array}$ & $\begin{array}{l}\text { Nahapiet and } \\
\text { Ghoshal (2000); } \\
\text { Putnam (2000); } \\
\text { Estrin et al. } \\
\text { (2013) }\end{array}$ \\
\hline \multirow{7}{*}{$\begin{array}{l}\text { Relational } \\
\text { social } \\
\text { capital }\end{array}$} & Trust & $\begin{array}{l}\text { Trust affects knowledge } \\
\text { transfer, individual } \\
\text { expectations and the } \\
\text { motivation to cooperate. }\end{array}$ & $\begin{array}{l}\text { Nahapiet and } \\
\text { Ghoshal (1998); } \\
\text { Inkpen and Tsang } \\
\text { (2005); Chang } \\
\text { and Chuang } \\
\text { (2011); Wu et al. } \\
\text { (2017); }\end{array}$ \\
\hline & Norms & $\begin{array}{l}\text { The social norms } \\
\text { represent the degree of } \\
\text { consensus in society. }\end{array}$ & $\begin{array}{l}\text { Nahapiet and } \\
\text { Ghoshal (1998); } \\
\text { Schultz et al., } \\
\text { (2007) }\end{array}$ \\
\hline & Obligations & $\begin{array}{l}\text { Obligations denote a } \\
\text { commitment or duty to } \\
\text { conduct certain } \\
\text { activities in the future. }\end{array}$ & $\begin{array}{l}\text { Nahapiet and } \\
\text { Ghoshal (1998); } \\
\text { Zheng et al. } \\
\text { (2014); Du et al. } \\
\text { (2015) }\end{array}$ \\
\hline & Identity & $\begin{array}{l}\text { Identity is the process } \\
\text { whereby people see } \\
\text { themselves as one of the } \\
\text { group members. }\end{array}$ & $\begin{array}{l}\text { Nahapiet and } \\
\text { Ghoshal (1998); } \\
\text { Hoffman et al. } \\
\text { (2005); Hopkins } \\
\text { (2011); }\end{array}$ \\
\hline & Reciprocity & $\begin{array}{l}\text { Reciprocity refers to } \\
\text { actions which are } \\
\text { contingent on expected } \\
\text { rewards from others and } \\
\text { cease when the } \\
\text { expected rewards are } \\
\text { unfulfilled. }\end{array}$ & $\begin{array}{l}\text { Wasko and Faraj } \\
\text { (2005); Chiu et } \\
\text { al. (2006) }\end{array}$ \\
\hline & Commitment & $\begin{array}{l}\text { Commitment expresses } \\
\text { a sense of responsibility } \\
\text { to help others. }\end{array}$ & $\begin{array}{l}\text { Requena (2003); } \\
\text { Wasko and Faraj } \\
\text { (2005) }\end{array}$ \\
\hline & Communication & $\begin{array}{l}\text { The communication in a } \\
\text { social group can } \\
\text { generate the satisfaction }\end{array}$ & $\begin{array}{l}\text { Requena (2003); } \\
\text { Kromidha and } \\
\text { Robson (2016) }\end{array}$ \\
\hline
\end{tabular}




\begin{tabular}{|c|c|c|c|}
\hline & & $\begin{array}{l}\text { and well-being among } \\
\text { the people in the group. }\end{array}$ & \\
\hline \multirow{5}{*}{$\begin{array}{l}\text { Cognitive } \\
\text { social } \\
\text { capital }\end{array}$} & $\begin{array}{l}\text { Shared } \\
\text { language }\end{array}$ & $\begin{array}{l}\text { Shared language can } \\
\text { promote the } \\
\text { understanding of } \\
\text { collective targets and } \\
\text { appropriate behaviours } \\
\text { in groups. }\end{array}$ & $\begin{array}{l}\text { Nahapiet and } \\
\text { Ghoshal (1998); } \\
\text { Tsai and Ghoshal } \\
\text { (1998); Inkpen } \\
\text { and Tsang } \\
\text { (2005); Chiu et } \\
\text { al. (2006) }\end{array}$ \\
\hline & $\begin{array}{l}\text { Shared } \\
\text { narratives }\end{array}$ & $\begin{array}{l}\text { Shared narratives within } \\
\text { a community increase } \\
\text { the creation and transfer } \\
\text { of the understanding of } \\
\text { events. }\end{array}$ & $\begin{array}{l}\text { Nahapiet and } \\
\text { Ghoshal (1998); } \\
\text { Huysman and de } \\
\text { Wit (2004) }\end{array}$ \\
\hline & Shared goals & $\begin{array}{l}\text { Shared goals illustrate } \\
\text { the degree to which } \\
\text { community members } \\
\text { share common } \\
\text { cognition and methods } \\
\text { of the group tasks. }\end{array}$ & $\begin{array}{l}\text { Inkpen and Tsang } \\
\text { (2005); Chow } \\
\text { and Chan (2008); } \\
\text { Bartsch et al. } \\
\text { (2013) }\end{array}$ \\
\hline & Shared culture & $\begin{array}{l}\text { Shared culture means } \\
\text { the degree to which } \\
\text { social norms affect the } \\
\text { relationships. }\end{array}$ & $\begin{array}{l}\text { Inkpen and } \\
\text { Tsang, 2005; } \\
\text { Villena et al. } \\
\text { (2011) } \\
\end{array}$ \\
\hline & Shared value & $\begin{array}{l}\text { Shared value bind the } \\
\text { network members, } \\
\text { facilitating cooperative } \\
\text { action. }\end{array}$ & $\begin{array}{l}\text { Cohen et al. } \\
\text { (2001) }\end{array}$ \\
\hline
\end{tabular}

It is important to note that different facets of each dimension of social capital interact with each other. For instance, in the relational dimension, obligations within networks lead to collective trust and reciprocity (Hoffman et al. 2005). Different dimensions of social capital also affect each other, (e.g., networks can facilitate the transmission of a person's trustworthiness within the network) (Wu et al. 2017) and generate a sense of obligation among individuals (Shane and Cable 2002), while the social norms provide the foundation for a shared culture (Inkpen and Tsang 2005).

Based on the summary of the facets of social capital, we expanded the search scope from the crowdfunding research which explicitly mentions 'social capital' to those involving some facets of social capital when we collected related literature. Therefore, we can cover all facets of social capital to thoroughly analyse the effects of social capital on crowdfunding campaigns, the 
development of social capital on crowdfunding platforms and the interactions between dimensions of social capital.

\section{Literature collection, synthesis and analysis}

The goal of this research is to synthesise the crowdfunding research, which involves the concept of social capital to establish a systematic model to explain how different dimensions of social capital interplay with each other and affect crowdfunding. Therefore, we needed to collect relevant research on social capital and crowdfunding first, then summarise how different facets of social capital influence crowdfunding performance, and finally establish a theoretical model based on this summary.

The procedure to collect papers was as follow (see Figure 1). We searched literature through the Web of Science and Google Scholar using a combination of keywords from two categories: 'crowdfunding' and 'social capital' (see Figure 1). To ensure the quality of the papers, we only kept the papers from the Science Citation Index Expanded (SCIE), the Social Sciences Citation Index (SSCI), top conferences (e.g., Association for Computing Machinery Conference in Computer Science) and highly influential online working papers (those which have been cited by papers from the SSCI or SCIE). 


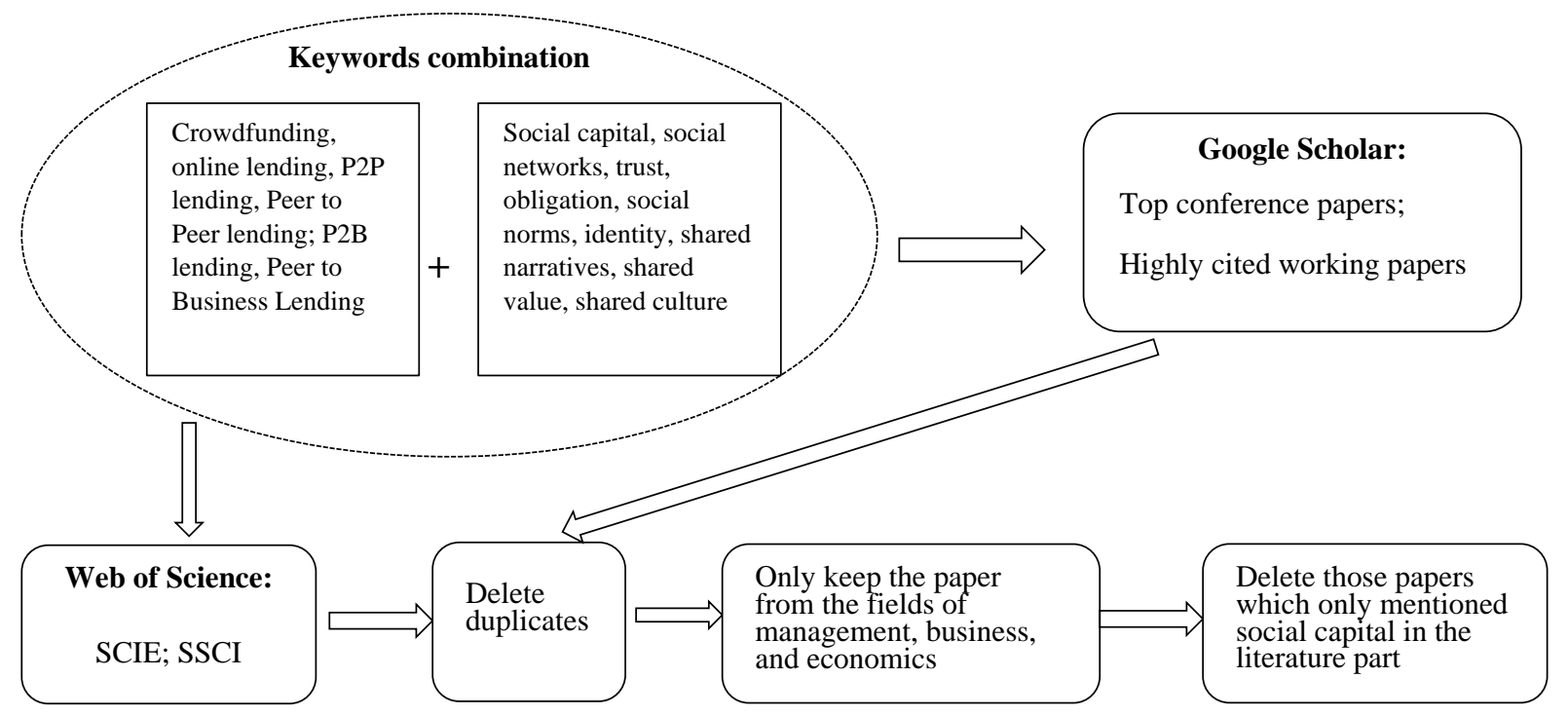

Figure 1. The flow diagram of the literature collection

This produced 221 papers in total, but some of them are repetitively counted in different rounds of searching (e.g., the paper covering structural, relational and cognitive social capital could be counted three times when searching the combination of 'social networks', 'obligation' and 'shared value' with 'crowdfunding'). Thus, we first deleted those duplicates. In the next step, after browsing their abstracts, we removed papers from other fields (e.g., law or medicine) and only kept those from the fields of business, management, economics, information science, operations research, communication, sociology and social sciences. Finally, we eliminated those which only mentioned social capital but did not deal with it specifically.

Consequently, we found 63 papers on the relationship between social capital and crowdfunding in total, six of which are literature reviews. The distribution of annual publications on crowdfunding and social capital can be seen in Figure 2. We can see that the number of articles related to the 
relationship between social capital and crowdfunding have increased significantly since 2015. (We only collected papers published before July 2018.)

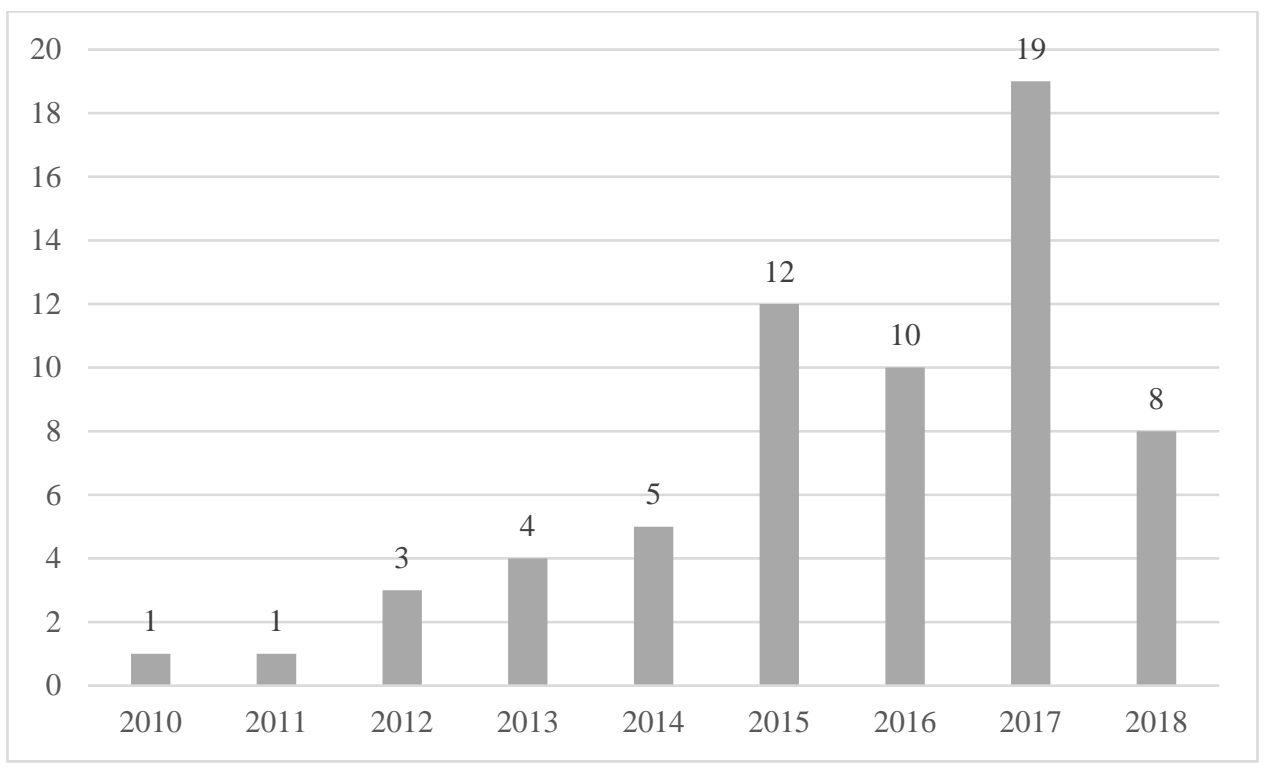

Figure 2. Publications on social capital and crowdfunding each year

The papers cover all dimensions of social capital and all types of crowdfunding (see Figure 2) (literatures are excluded). We can see that cognitive social capital is less frequently discussed in comparison with the other two dimensions. Only a few studies take two dimensions of social capital into account, and there is only one paper covering all three dimensions of social capital. As for different types of crowdfunding, scholars paid little attention to donation crowdfunding. Donation crowdfunding and reward-based crowdfunding were always studied together in early crowdfunding research because those authors considered these nonfinancial crowdfunding activities as an entrepreneurial finance other than P2P lending (e.g., Gerber and Hui 2013; Gerber et al. 2012; Hui et al. 2014). Forty-five of them are empirical studies. (Their main arguments and empirical results can be seen in the Appendix.) 


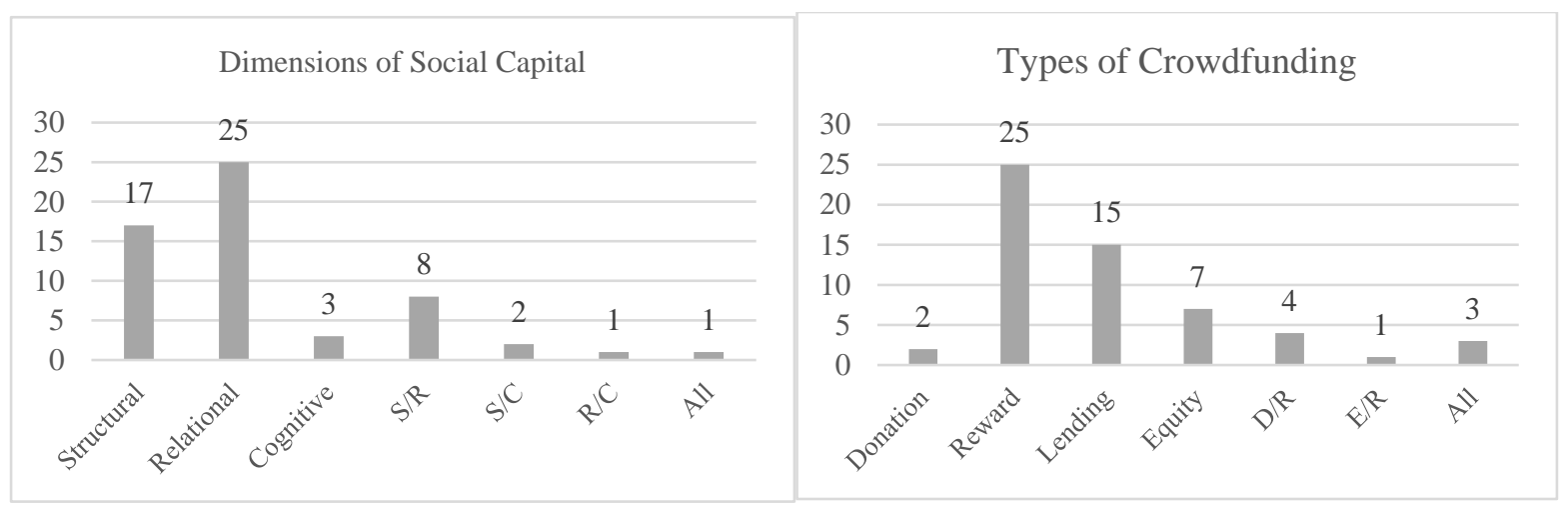

Figure 3. Empirical studies on each dimension of social capital and each type of crowdfunding

The relationships between different facets of social capital and each type of crowdfunding performance are summarised in Table 2. We can see that almost all research demonstrated a positive relationship between social capital and crowdfunding performance. However, some facets of social capital (e.g., obligation and reciprocity) play a more important role in reward-based crowdfunding than in other types, while most studies ignored donation crowdfunding in their discussion. 
Table 2. Summary of Research on Social Capital and Crowdfunding

\begin{tabular}{|c|c|c|c|c|c|}
\hline Dimension & Facet & Donation & Reward-Based & Lending & Equity \\
\hline Structural & Social networks & + & + & + & + \\
\hline \multirow{5}{*}{ Relational } & Trust & + & + & + & + \\
\hline & Obligation/ Reciprocity & NA & + & NA & NA \\
\hline & Identity & NA & + & + & + \\
\hline & Commitment & NA & + & NA & NA \\
\hline & Communication & + & + & + & + \\
\hline \multirow{2}{*}{ Cognitive } & Shared value & NA & + & NA & NA \\
\hline & Shared goal & NA & + & NA & NA \\
\hline
\end{tabular}

Based on these studies, we develop propositions regarding how each facet of social capital affects crowdfunding performance. The analysis reveals that different dimensions of social capital do not affect crowdfunding separately, but that they may interact with each other, thereby influencing crowdfunding performance. Prior studies suggested that there are both formal communities (the communities formed because of the platform's requirement) and informal communities in crowdfunding. Both formal and informal communities play an important role in investors' interactions, thereby affecting their funding intentions. Previous research suggested that virtual communities are online networks in which community members share knowledge, thereby influencing both personal and community outputs (Chiu et al. 2006). Therefore, we integrate these studies by introducing virtual communities into crowdfunding research and build a theoretical model upon them. 


\section{Structural social capital and crowdfunding}

Prior research shows that social networks can promote entrepreneurship because the social network ties between entrepreneurs and investors help reduce information asymmetries (Shane and Cable 2002), reduce uncertainty (Leyden et al. 2014) and enhance the collaboration in groups and promote innovation (Bercovitz and Feldman 2011). In the emerging body of crowdfunding literature, mainly the entrepreneurs' social network size and the heterogeneity of the impact of different social network ties on crowdfunding performance are considered as determinants of crowdfunding success.

\section{Entrepreneurs' social network size and crowdfunding}

Early research on crowdfunding focusses on finding the determinants of crowdfunding success (e.g., Mollick 2014; Ahlers et al. 2015; Vismara 2016a). A survey conducted by Nesta in 2014 suggested that two-thirds of UK fundraisers treat their social network as one of the key elements contributing to the success of crowdfunding campaigns (Vismara 2016a). There is a huge uncertainty in crowdfunding campaigns. Ahlers et al. (2015) applied signal theory to crowdfunding research, arguing that start-ups need to signal their true value to small investors, and entrepreneurs' social networks are a costly signal. Other scholars follow this approach and test whether an entrepreneur's social network is an effective signal for reflecting the project's value (e.g., Kromidha and Robson 2016; Vismara 2016a; Kunz et al. 2017). Research conducted in a similar manner stresses the role of social networks in crowdfunding by arguing that social networks can mitigate information asymmetry (Zheng et al. 2014), help entrepreneurs form their mutual identity (Kromidha and Robson 2016) and enable entrepreneurs access to more resources (Saxton and Wang 2014). 
Most researchers measured a social network as the number of friends on social media (e.g., Facebook, LinkedIn and Sina Weibo), and they found that entrepreneurs' social network size has a positive influence on fundraising success in donation-based crowdfunding (Saxton and Wang 2014), reward-based crowdfunding (Giudici et al. 2013; Mollick 2014; Zheng et al. 2014), lendingbased crowdfunding (Freedman and Jin 2017) and equity crowdfunding (Vismara 2016a). Many crowdfunding studies also involve social capital as a control variable and demonstrate a positive association between social network and crowdfunding success (e.g., Mollick 2014; Butticè et al. 2017; Skirnevskiy et al. 2017).

However, some researchers who choose factors other than the number of online friends find different effects. Ahlers et al. (2015) used the share of non-executive directors on ventures' boards to measure social networks and found that social networks have no impact on crowdfunding success. Chen et al. (2016) measured social network size as the number of community members on the lending crowdfunding platform Prosper Marketplace. They observed that larger group network size leads to less group cohesion and is negatively associated with crowdfunding performance.

\section{Different types of social networks and crowdfunding}

Previous research usually classified social network ties into strong ties and weak ties. There are different types of relationships in crowdfunding communities: kinship relations (Borst et al. 2018), friendship (Gerber et al. 2012; Lin et al. 2013) and perceptual relations (i.e., being unknown or known to each other) (Borgatti et al. 2014). Earlier studies mainly considered the first two types of relationship as social capital, while in online contexts, technologies make it easier for individuals to contact total strangers. In online communities, the Internet-based linkages are essential to the formation of weak ties (Ellison et al. 2007). Therefore scholars put forward the concept of 'latent 
ties', which refers to connections which are technically possible but have not been activated yet (Ellison et al. 2011). Such latent ties can be considered a resource embedded in virtual communities; consequently, we consider latent ties as a type of structural social capital. Earlier work indicated several differences in the influence of a diverse set of social network ties on crowdfunding campaigns.

First, ties affect crowdfunding in different stages of the campaign. In the early stage of crowdfunding campaigns, the investment accumulates quickly due to the early backers who are directly connected to the project owners, while in the second period, the funds accumulate slowly because the process depends on the social networks of investors and the recommendations made from person to person (Ordanini et al. 2011; Agrawal et al. 2015; Davidson and Poor 2016). Second, social ties also affect investors’ funding motives. Polzin et al. (2018) suggested that crowdfunders with strong ties and weak ties to fundraisers are motivated to invest in a project not only for financial return but also to maintain a good relationship with the fundraisers; therefore, these investors base their decision-making on the information about the project owner instead of the information about the project. Third, social network ties influence how investors obtain project information. Agrawal et al. (2015) suggested that family and friends, who represent the strong ties, have other channels besides the crowdfunding platform to communicate with creators. In contrast, weak ties and latent ties mainly search for information on the platform and other social media; therefore, social media can help to attract more weak ties in crowdfunding campaigns (Borst et al. 2018).

\section{Relational social capital and crowdfunding}

Whereas structural social capital determines the range of potential funders within a fundraiser's reach, the relational social capital determines the possibility that an investment will be fulfilled 
(Zheng et al. 2014). Zheng et al. (2014) introduced the term 'relational social capital' in the crowdfunding literature, triggering research which involves different facets of relational social capital.

\section{Trust and crowdfunding}

Trust plays an important role in entrepreneurial financing. MacMillan et al. (2005) found trust to be the key in affecting supporters' intention to donate. Meanwhile, venture capitalists' decisionmaking is also affected by trust (Bottazzi et al., 2011). Crowdfunding platforms accumulate trust between entrepreneurs and investors as backers are motivated to support the entrepreneurs they trust (Gerber and Hui 2013). However, this research on trust and crowdfunding performance did not follow a consistent classification of trust. Kshetri (2017) distinguished trust into thin trust (trust among strangers) and trust in the Internet (the confidence in the Internet as a reliable place to conduct transactions). Chen et al. (2014) divided trust into trust in other borrowers (fundraisers) and trust in the intermediary (platforms), while Kang et al. (2016) classified trust into calculus trust (derived from outcome valuation) and relationship trust (derived from relationships). Thus, we reconciled different classifications by introducing a new classification of trust.

Trust is 'a psychological state comprising the intention to accept vulnerability based upon positive expectations of the intentions or behavior of another' (Rousseau et al. 1998). Based on individual trust beliefs, trust can be distinguished into integrity-based trust and competence-based trust (Connelly et al. 2018). Competence-based trust refers to the trustor's perception that the trustee possesses the interpersonal and technical competencies to finish his or her job (Butler and Cantrell 1984). Integrity-based trust is rooted in perceptions about the trustee's honesty, character and motives (Sitkin and Roth 1993). An example of competence-based trust in crowdfunding can be trust in the entrepreneurial abilities of the project creator (Butticè et al. 2017; Skirnevskiy et al. 
2017; Yum et al. 2012). Such competence-based trust reflects the idea that fundraisers' creditworthiness can be measured by successful crowdfunding experience and investments in other projects (Zheng et al. 2016). Beyond competence-based trust in the project creator, there is also crowdfunding research on competence-based trust in platforms, for example by Chen et al. (2014), who measured (competence-based) trust with questionnaires which asked investors to what degree they believe the platform could protect their benefits.

As for integrity-based trust, Zheng et al. (2016) measured trust by entrepreneur-sponsor interactions because these interactions show the entrepreneurs' intentions to move the project forward and reduce sponsors' perceived risks. Fundraisers' certifications (e.g., ID verification, phone number, diploma and transaction history) also contributes to the success of crowdfunding campaigns (Xu et al. 2015). These certifications relate to integrity-based trust because exposing personal information reflects entrepreneurs' intent to raise money rather than to deceive people. Another measurement of integrity-based trust is through a survey. Similarly, Kang et al. (2016) used the term 'relationship trust' to represent the relational-based trust measured by repeated interactions. Chen et al. (2014) only asked investors some general questions, such as whether the fundraisers are benevolent. Surveys on trust towards strangers (e.g., the World Values Survey) also measure integrity-based trust. All research suggests that trust is positively associated with crowdfunding performance.

\section{Obligation, reciprocity and crowdfunding}

Obligation and reciprocity are mainly discussed in reward-based crowdfunding (Zheng et al. 2014; Colombo et al. 2015). Internal social capital triggers reciprocity through a feeling of perceived obligation (Tsai and Ghoshal 1998). Entrepreneurs who receive funding from others may feel 
obliged to support by giving back; thus, this obligation is called specific reciprocity (Zheng et al. 2014; Colombo et al. 2015).

The obligation is measured by the fundraisers' backing activities. As the entrepreneur backed a specific investor's projects before, this investor may feel it is his or her duty to return the favour (Zheng et al. 2014; Colombo et al. 2015). Zheng et al. (2014) measured obligation as the number of others' projects in which an entrepreneur invested before the expiration of his or her own crowdfunding, and they found that the obligation to fund other entrepreneurs has a positive impact on crowdfunding performance. Colombo et al. (2015) emphasised that internal social capital, which consists of obligation and reciprocity, promotes the success rate of crowdfunding campaigns by attracting more early contributions. Similarly, Butticè et al. (2017) measured backing activities as the number of comments which the proponent had posted on backed projects and found that this type of social capital also has a positive effect on project success.

Reciprocal giving develops a certain relationship with a crowdfunding platform, fostering project success, while non-reciprocal giving has a negative influence on crowdfunding success (André et al., 2017). Other researchers indicated that both direct reciprocity (owners tend to support their backers) and indirect reciprocity (owners tend to support people who have backed others) have a positive impact on crowdfunding success (Zvilichovsky et al. 2015).

\section{Identity and crowdfunding}

In crowdfunding, identity affects people’s behaviour and the reasoning behind why they invest; thus, people are more likely to support projects which are consistent with their own identity (Gerber and Hui 2013). Colombo et al. (2015) suggested that crowdfunding proponents share a sense of mutual identity. In the example of the Kickstarter platform, some proponents establish a rule called 
'Kicking It Forward', which asks proponents who have received funds from Kickstarter to systematically invest $5 \%$ of their profits to back other projects.

Crowdfunding research emphasises the interaction between social identity and other types of social capital. For example, group identity, measured as whether the entrepreneurs use the term 'we' or ‘together', can help entrepreneurs engender effective commitments among investors and eventually encourage funders to back the project in the form of financial capital (Allison et al. 2017). Other scholars applied social identity theory in crowdfunding research. Social identity plays an important role in investors' decisions in the crowdfunding community. In lending crowdfunding, social identity features affect an investors' funding motivation in two ways. First, the social networks associated with the identity of borrowers within the networks affect the probability that borrowers repay the investment and the lender's decision-making. Second, offline external social identity can be used to judge borrowers' reliability online (Feller et al. 2017). Chen et al. (2017) measured social identity as whether borrowers belong to a team, and they found that social identity has a positive influence on crowdfunding performance. Ai et al. (2016) also measured social identity as group membership and confirmed that social identity increases lending activities in a field experiment.

Social identity theory is also applied in reward-based crowdfunding. Kromidha and Robson (2016) measured social identity as the number of shares of project information on personal Facebook pages by supporters and found that the degree to which investors identify themselves as group members is positively associated with a project's success. Other researchers used similar concepts as proxies for social identities, such as group cohesion, which means the interdependencies among group members (Chen et al. 2016). The authors suggested that group cohesion affects the efficiency of social connection in the group, thereby increasing the project's success rate. 


\section{Other facets of relational social capital and crowdfunding}

There are single studies on other facets of relational social capital. Based on social exchange theory, Zhao et al. (2017) argued that establishing a backer's commitment spurs a backer's intention to invest in a crowdfunding campaign. Giudici et al. (2018) found that localised compliance with social norms enhances the positive effect of local altruism on crowdfunding performance. While Gleasure and Morgan (2018) argued that social norms affect crowdfunding by establishing, refining or adjusting the nature of community, subject and rules.

Communication can be considered another type of relational social capital (Requena 2003). On crowdfunding platforms, fundraisers communicate with investors through commenting, updating and Q\&As. Prior research indicated that the number of comments is positively associated with crowdfunding performance (Mollick 2014; Cho and Kim 2017). Recent work found that whether the comments are positive, irrelevant and accurate also affects funding success (Xu and Chau 2018). Apart from comments, project updates are another form of communication, because they reflect efforts by founders to inform funders about developments on the project (Mollick 2014; Block et al. 2018). Moreover, the Q\&A of a campaign provides a channel for investors to request more information from fundraisers. Lee and Lee (2012) demonstrated a positive relationship between the number of Q\&As posted online and crowdfunding performance.

\section{Cognitive social capital and crowdfunding}

In contrast to structural and relational social capital, cognitive social capital is discussed relatively rarely in crowdfunding research. To our knowledge, Zheng et al. (2014) is the only empirical study which involves the relationship between cognitive social capital and crowdfunding performance. The study measures cognitive social capital as project description length. However, other scholars 
argue that this measurement cannot represent cognitive social capital (Skirnevskiy et al. 2017). Hence, it is worthwhile exploring the relationship between crowdfunding performance and some facets of cognitive social capital, among which shared value is most frequently discussed.

\section{Shared value and crowdfunding}

Shared value reflects the degree of consensus among network members (Morgan and Hunt 1994).

Previous research indicated that shared value positively associates with trust and commitment in social recommendation systems (Chang and Hsiao 2013); computer, communications and consumer electronics product retailing (Jih et al. 2007); and not-for-profit organisations (MacMillan et al. 2005). Crowdfunding is not only driven by economic benefits but also by a set of shared values which unify a group of investors and anchor them to certain projects (Butticè et al. 2017; Gleasure and Feller 2016). Shared values in the crowdfunding community not only directly affect investors' identity in the virtual community (Gleasure and Feller 2016) but also make it easier for serial crowdfunders to fund their projects (Butticè et al. 2017).

We find two empirical papers on shared values and crowdfunding. Zhao et al. (2017) argued that there is a high level of trust and commitment between backers and fundraisers in reward-based crowdfunding if they share similar values. Josefy et al. (2017) found that shared values within a community are related to collective beliefs, trust, judgement, cooperation and aligned behaviours. Meanwhile, these shared values encourage funders to shift their funding intentions from selfinterest towards more collective benefits for the whole community. Their empirical results substantiate that the degree to which a campaign goal is consistent with community culture positively affects crowdfunding performance. 


\section{Other cognitive social capital and crowdfunding}

Other cognitive social capital includes shared language, narratives, goals and culture. Previous research indicated that there are significant cultural differences in crowdfunding platforms from different countries, and cultural difference moderates the effect of social capital on crowdfunding performance (Zheng et al. 2014). Specifically, Burtch et al. (2013) showed that cultural differences (i.e. the national cultural differences between lenders and borrowers) have a negative influence on online lending actions.

Moreover, crowdfunding performance is related to language and narrative style (Anglin et al. 2018; Block et al. 2018). The following studies are related to cognitive social capital theory. For instance, Allison et al. (2015) applied the cognitive evaluation theory to explain how the language use of entrepreneurs affects backers' funding motivations. Another concept which is similar to cognitive social capital is 'collective language'. Collective language stresses the distinctiveness of the group and enhances the saliency of the identity in members' self-concepts (Shamir et al. 1993). Allison et al. (2017) demonstrated that collective language can function as peripheral cues to enhance crowdfunders' motivation to invest.

Shared language and culture also interplay with other factors contributing to crowdfunding success, including some facets of social capital, such as group identity (Reiche et al. 2015), communications (Chiu et al. 2006) and social norms (Inkpen and Tsang 2005), as well as other factors such as geography (Burtch et al., 2013). Cognitive social capital may also affect crowdfunding performance indirectly through the mediation effect of these factors.

Summing up, cognitive social capital impacts on crowdfunding through online virtual communities. The social capital embedded in a 'virtual community', including shared values and shared language, 
can affect community-related outcomes (i.e., crowdfunding campaign performance in crowdfunding communities) via enhanced knowledge sharing (Chiu et al. 2006). From the perspective of cognitive social capital, backers who actively provide information on specific projects can also share their values and narratives in the community (Skirnevskiy et al. 2017).

\section{A synthesis}

\section{From crowds to virtual communities}

For understanding the phenomenon of crowdfunding and in particular the role of social capital, a virtual community is a better unit of research than crowds. A virtual community can be defined as 'online social networks in which people with common interests, goals, or practices interact to share information and knowledge, and engage in social interactions’ (Chiu et al. 2006, p. 1873). A virtual community is superior to crowds to study the relationship between social capital and crowdfunding in two respects.

First, virtual communities are a network-based concept, stressing the role of different types of social capital in communities (e.g., shared goals, network ties and communication). On one hand, social capital contributes to the formation of a virtual community by unifying a group of individuals who share the same values, culture and goals (Butticè et al. 2017; Josefy et al. 2017). Therefore, investors with similar values and goals invest together in certain projects consistent with their shared values. On the other hand, the crowdfunding activities in the community (e.g., backing, launching or updating a crowdfunding campaign; following or investing in a project; and posting comments on projects) in turn enhance the development of social capital embedded in the communities. 
On some platforms, investors are required to join communities to make an investment. For example, on the U.S. equity crowdfunding platform AngelList, investors must join a syndicate to invest in a project. Similarly, in the British equity crowdfunding platform SyndicateRoom, investors can follow a lead investor to make the decision. Individuals can also establish communities through other types of platforms (e.g., Prosper Marketplace (Lin et al. 2013; Chen et al. 2016) and Kickstarter (Colombo et al., 2015). Therefore, taking the virtual community into account in research on the relationship between social capital and crowdfunding performance has not only academic value but also practical implications.

\section{Social capital in virtual communities}

Structural social capital: In crowdfunding communities, entrepreneurs' strong ties include family and friends. The weak ties consist of acquaintances, friends of friends, customers or visitors (Bruton et al. 2015; Polzin et al. 2018). Specifically, investors who have been backed by the entrepreneurs before are a type of weak ties which to some extent substitute for the strong ties, because they play an important role in the early stage of funding (Colombo et al. 2015; Butticè et al. 2017), while latent ties contain strangers who have the potential to form ties with existing networks via crowdfunding activities (Borst et al. 2018).

Relational social capital: Trust and obligation are the two facets embedded in strong ties. Agrawal et al. (2015) suggested that family and friends may invest in a project out of a sense of obligation. Polzin et al. (2018) showed that investors with strong ties to founders are motivated by the willingness to strengthen their relationship and obligation, and therefore tend to seek information about the founders instead of the projects, thereby increasing the trust in the relationship. 
In contrast to strong ties, which are mainly built through offline communications, both weak ties and latent ties are mainly developed online on crowdfunding platforms and through other social media (Borst et al. 2018). Therefore, we propose that weak ties and latent ties mainly affect crowdfunding performance through communication (e.g., the comments posted online and the updates of projects), commitment (Zhao et al. 2017) and group identity (Kromidha and Robson, 2016; Feller et al. 2017). However, investors who were backed by the entrepreneurs before are the exception, as they are motivated by obligation and reciprocity because they feel it is their duty to fund other entrepreneurs in the early stage of crowdfunding campaigns (Zheng et al. 2014; Colombo et al. 2015; Butticè et al. 2017).

Cognitive social capital: Cognitive social capital consists of shared values, shared culture, shared language and shared narratives, and it affects crowdfunding campaigns through different means. First, cognitive social capital serves as the foundation of the crowdfunding community by unifying a group of people who share similar goals and culture (Butticè et al. 2017). Cognitive social capital may also enhance the narrative effectiveness among group members, thereby affecting investors' evaluation of project quality (Nahapiet and Ghoshal 2000; Chiu et al. 2006). Therefore, cognitive social capital is related to the collective beliefs and goals in the community, making group members behave collectively to achieve the shared goals (Josefy et al. 2017).

\section{Virtual communities, crowdfunding activities and social capital}

Virtual communities hold different types of crowdfunding activities. Entrepreneurs can use example projects as models, find specialised expertise, run a campaign, broadcast their project and get feedback from others in the community, while investors can follow a project, share the project with their own social media, post comments and discuss the project with other investors (Hui et al. 2014). Such crowdfunding activities are the interplay among community members and are to some 
extent driven by community-related characteristics, such as the wisdom of crowds and collective goals.

These activities in crowdfunding communities generate or shape all dimensions of social capital. The size of entrepreneurs' social networks increase because of referrals inducing potential backers (Skirnevskiy et al. 2017). Meanwhile, social media activities attract more potential social network ties (Borst et al. 2018). For relational social capital, backing activities engender obligation among project creators and investors (Colombo et al. 2015) and online communication enhances trust between backers and entrepreneurs (Zheng et al. 2016). As for cognitive social capital, investors are likely to share their values and narratives when they transfer information on the crowdfunding platform (Skirnevskiy et al. 2017). Gleasure and Feller (2016) also suggested that shared values among community members can be generated and shaped by the dialogues possessing a set of espoused values among investors. As we discussed earlier, all these facets of social capital contribute to crowdfunding success.

Meanwhile, different facets of social capital also interplay with others. For example, if the community members share the same goals and values, they are more likely to consider themselves as members of a community, thereby enhancing their identification with the community. Previous research indicated that social identity is related to trust, and a higher level of trust can promote the commitments of the fundraisers (Zheng et al. 2016; Zhao et al. 2017). Therefore, researchers should not study different types of social capital independently. We stress the entanglement of different facets of social capital in crowdfunding research to provide a deeper understanding of how social capital affects crowdfunding performance. The multidimensional nature of social capital embedded in a virtual community is represented in Figure 4. 


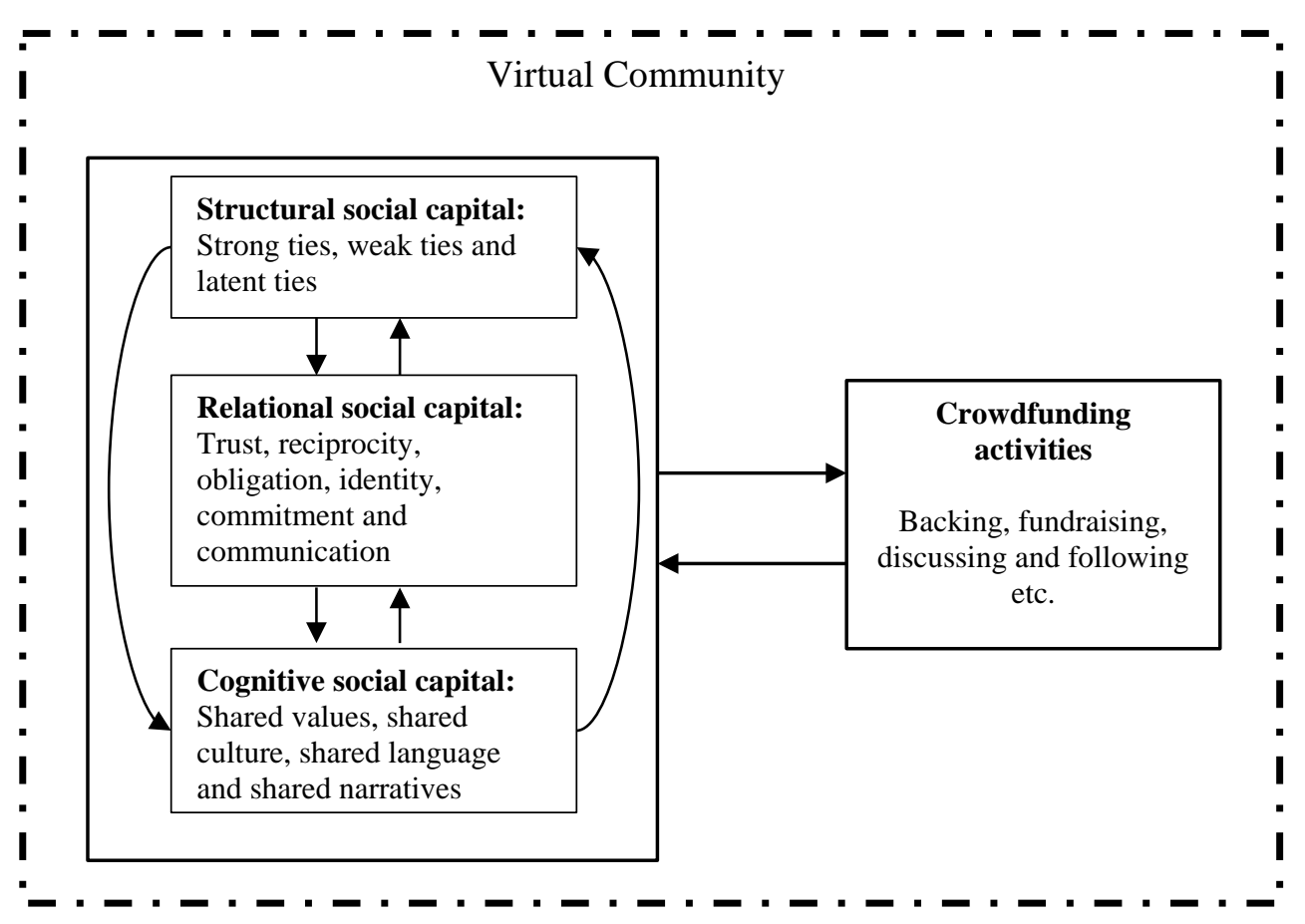

Figure 4. Multidimensional social capital in a virtual community

\section{Crowdfunding campaigns over time: A three-phase model}

To capture the dynamic of crowdfunding campaigns, we should take the development phase of the project into account because the effect of social capital on crowdfunding performance varies over time. In virtual communities, investors also react differently at different stages. Ordanini et al. (2011) suggested that there is a temporal dimension in a reward crowdfunding campaign consisting of three stages. The first stage is termed the 'friend-funding phase', which features a quick accumulation of funding reaching about half of the target capital. The second phase is 'getting to the crowdfunding', represented by a slow-down in the growth of funding accumulation. Not all campaigns can reach the third phase, the 'engagement moment', in which the funding speeds up towards the target (see Figure 5). 


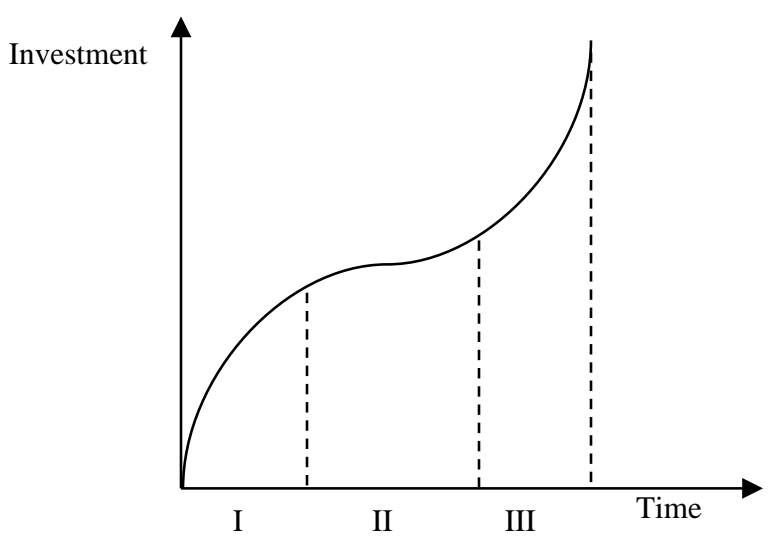

Figure 5. Typical path of investment via a crowdfunding platform

(Source: Ordanini et al., 2011)

In the other types of crowdfunding, we can find similar characteristics. Friends and family also play an important role in lending crowdfunding (Lin et al. 2013) and equity crowdfunding (Lukkarinen et al. 2016; Polzin et al. 2018). Specifically, Lukkarinen et al. (2016) suggested that private social networks, which consist of friends and family, also contribute to the accumulation of early funding. Meanwhile, there is empirical evidence to support the features of Phase III. Colombo et al. (2015) argued that a sufficient amount of early contributions in a reward crowdfunding campaign can trigger a self-reinforcing mechanism, thereby accelerating the accumulation of total funding, while the previous investments lead to herding behaviours in lending crowdfunding campaigns (Luo and Lin, 2013; Liu et al. 2015). As for equity crowdfunding, the funds raised in the early stage of crowdfunding campaigns result in an information cascade among investors, thereby increasing the chance that the project will be fully funded (Vismara, 2016b).

Based on our analysis, we propose that this three-phase model fits all types of crowdfunding campaigns. Distinguishing three stages in crowdfunding campaigns helps us develop a deeper 
understanding of how social capital affects crowdfunding. Moreover, the effects of different facets of social capital on crowdfunding performance vary in different phases, while some facets also interplay with other facets of social capital during campaigns. Therefore, we build a three-phase model to elaborate on how different facets of social capital interact with each other in different stages to promote the crowdfunding performance (see Figure 6).

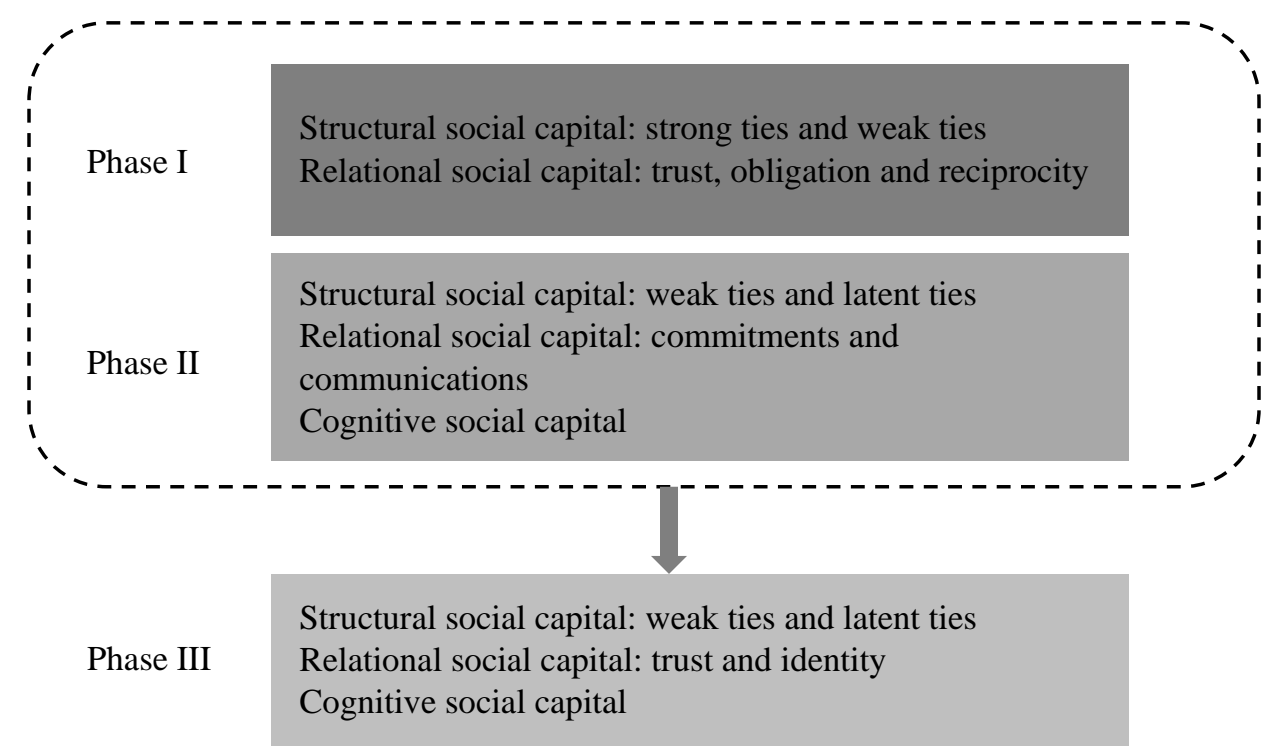

Figure 6. Three-phase model of crowdfunding campaigns

Phase I. In the early stage of crowdfunding, fundraisers receive support not only through their strong ties but also by investors who were backed by the same entrepreneurs before. Previous research indicated that these reciprocal backers (Colombo et al. 2015; Butticè et al. 2017; Skirnevskiy et al. 2017) and family and friends (Ordanini et al. 2011; Agrawal et al. 2015) play an important role in this phase. For those strong ties, trust and obligation make them willing to take the risk to invest in the projects to maintain a good relationship with the project owners, while the reciprocal backers are mainly driven by the sense that it is their duty to support the entrepreneurs. 
Phase II. This period is funded by both weak ties and latent ties. These investors are mainly driven by financial returns, and therefore need to assess the quality of the projects, which requires due diligence, making the funding accumulate slowly. The commitments made by fundraisers and communications in the community can reduce the perceived risks and encourage funders to support the projects (Feller et al. 2017; Zhao et al. 2017). Moreover, previous research suggested that such knowledge sharing in the virtual community via communication affects the community outcomes (Chiu et al. 2006) (i.e., crowdfunding success in a campaign). In the end, cognitive social capital, which relates to the narrative effectiveness, has a moderation effect on the relationship between relational social capital and crowdfunding performance.

Phase III. The difference between Phase II and III is that investors are motivated to follow other investors' decisions instead of evaluating the quality of projects. The funding accumulated in the earlier stages attracts a large number of investors by enhancing collective intelligence (Yum et al. 2012), reducing uncertainty (Colombo et al. 2015); causing information cascades (Vismara 2016b); and leading to herding behaviours (Liu et al. 2015; Mohammadi and Shafi 2018). The selfreinforcing mechanism is triggered by the fact that members in the virtual communities affect others' decision-making.

Vismara (2016b) specifically found that investors with links to social media are more easily able to trigger an information cascade. In contrast, investors concealing their names and the amounts of their investments reduces subsequent investors' funding intentions (Burtch et al. 2016). The link on the project page to entrepreneurs' social media also increases the level of trust because social media can certify investors' identities, making them more trustworthy. Previous research suggested that Facebook use is related to social trust among people (Valenzuela et al. 2009) (i.e., integritybased trust). Both group identity and cognitive social capital can unite group members, leading to 
collective behaviours among group members (Josefy et al. 2017; Pan et al. 2007). Therefore, we suggest that trust, group identity and cognitive social capital are essential at this stage.

\section{Conclusions and avenues for future research}

Crowdfunding is inherently a social phenomenon. To improve our understanding of the crowdfunding phenomenon and its success, we systematically reviewed the literature on social capital and crowdfunding. We classified social capital into three dimensions: structural social capital, relational social capital and cognitive social capital. By discussing the key literature on social capital, we provided a comprehensive summary of the elements of each dimension of social capital. Based on this classification, we reviewed research on the facets of social capital, such as trust, identity and reciprocity. Most studies indicated that all dimensions of social capital are positively associated with crowdfunding performance, while only a few empirical results showed that social capital has no effects on crowdfunding. Based on this analysis, we find promising fields for future crowdfunding and social capital research.

\section{Empirical research on cognitive social capital and crowdfunding}

There is relatively little empirical research on the relationship between cognitive social capital and crowdfunding performance, which points towards a need to identify cognitive social capital. One possible solution is to measure cognitive social capital with surveys and appropriate questionnaire items (scales). Another proxy would be geographic proximity. Previous research indicated that geographic proximity positively relates to cultural similarity (Burtch et al. 2013). Residents who live close to each other are more likely to communicate with others, thereby sharing a similar language and culture. Consequently, geographic proximity with other demographic factors can also reflect cognitive social capital. 


\section{Syndicate social capital}

Previous research emphasises the importance of building a crowdfunding community to support crowdfunding campaigns (e.g., Belleflamme et al. 2014; Hui et al. 2014). Different dimensions of social capital can be developed in the community, for instance, social network ties, group trust and identity and shared values and goals. Previous research indicated that venture capitalists (VCs) tend to syndicate their investments with other VCs, and that syndicate social capital affects VCs' decision-making through information diffusion (Sorenson and Stuart 2001). Similarly, syndicates exist on several crowdfunding platforms (e.g., SyndicateRoom in the UK and AngelList in the U.S). The leader-follower syndicate models are mainstream in the Chinese equity crowdfunding market. Agrawal et al. (2016) argued that syndicates reduce information asymmetries because the leaders in the syndicate have both the ability and incentive to leverage the information about the project. Future research may focus on this community and study how structural, relational and cognitive social capital within the syndicates affect crowdfunding performance.

\section{An institutional perspective}

As discussed earlier, social capital is also a type of informal institution (Kshetri 2017). The relationship between social capital and crowdfunding performance can be moderated by national culture, which also represents an informal institution (Zheng et al., 2014; Cho \& Kim, 2017). Formal institutions might also moderate the effect of social capital on crowdfunding performance. Another approach would be to study how social capital - as an informal institution - affects crowdfunding at the regional or national level. Previous research mainly focussed on individual social capital. Since social capital also exists at the macro level, from an institutional point of view, regional social capital such as local trust and the density of voluntary organisations may affect both individual crowdfunding campaigns and the regional crowdfunding volume. 


\section{Longitudinal research}

As an emerging source of entrepreneurial finance, crowdfunding has a relatively short history, meaning that all extant research by necessity focusses on a short-term effect of social capital on crowdfunding performance. As the development of the crowdfunding market advances, more comprehensive datasets may be possible to conduct longitudinal research. On the one hand, we can study how the effect of social capital on crowdfunding performance changes over time (especially when experiencing regulation shocks). On the other hand, we can trace those firms which succeeded in crowdfunding campaigns; for example, by studying how social capital affected the exit of a project or even the fundraising in the next round.

\section{Causality test}

Previous research on the relationship between social capital and crowdfunding performance only studied the correlation between these two factors. Thus, further causality tests are needed to examine whether social capital contributes to crowdfunding success. The methods to test the causality between social capital and crowdfunding success include instrumental variables and experiments. The instrumental variables have to be correlated with social capital but not with crowdfunding performance. In the experimental design, it is possible to test the causality between social capital and crowdfunding performance by controlling other variables in both control and treatment groups. 


\section{Appendix}

\section{Appendix I. Summary of empirical research on crowdfunding and social capital}

\begin{tabular}{|c|c|c|c|c|c|c|}
\hline Article & Dimension & Facet & Types & Measurement & Argument & Result \\
\hline $\begin{array}{l}\text { Saxton and } \\
\text { Wang } \\
\text { (2014) }\end{array}$ & Structural & $\begin{array}{l}\text { Social } \\
\text { network }\end{array}$ & Donation & $\begin{array}{l}\text { The number of } \\
\text { members on } \\
\text { Facebook Causes }\end{array}$ & $\begin{array}{l}\text { Social networks strongly } \\
\text { link to resource } \\
\text { acquisition; the members } \\
\text { of voluntary organisations } \\
\text { are more likely to donate. }\end{array}$ & Confirm \\
\hline $\begin{array}{l}\text { Giudici et } \\
\text { al. (2013) }\end{array}$ & Structural & $\begin{array}{l}\text { Social } \\
\text { network }\end{array}$ & $\begin{array}{l}\text { Reward- } \\
\text { based }\end{array}$ & $\begin{array}{l}\text { The number of } \\
\text { Facebook friends }\end{array}$ & $\begin{array}{l}\text { Social networks can } \\
\text { signal the quality of the } \\
\text { projects, and territorial } \\
\text { social capital can } \\
\text { moderate the effect of } \\
\text { social network on } \\
\text { crowdfunding success. }\end{array}$ & 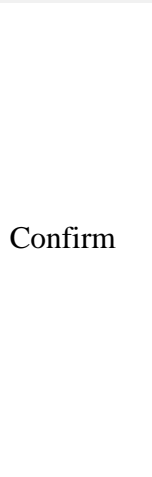 \\
\hline $\begin{array}{l}\text { Mollick } \\
\text { (2014) }\end{array}$ & Structural & $\begin{array}{l}\text { Social } \\
\text { network }\end{array}$ & $\begin{array}{l}\text { Reward- } \\
\text { based }\end{array}$ & $\begin{array}{l}\text { The number of } \\
\text { Facebook friends }\end{array}$ & $\begin{array}{l}\text { Social networks as } \\
\text { control variables }\end{array}$ & Confirm \\
\hline $\begin{array}{l}\text { Zheng et al. } \\
\text { (2014) }\end{array}$ & $\begin{array}{l}\text { Structural/ } \\
\text { relational/ } \\
\text { cognitive }\end{array}$ & $\begin{array}{l}\text { Social } \\
\text { network }\end{array}$ & $\begin{array}{l}\text { Reward- } \\
\text { based }\end{array}$ & $\begin{array}{l}\text { Facebook or Sina } \\
\text { Weibo } \\
\text { friends/backing } \\
\text { activates/length of } \\
\text { the project } \\
\text { description }\end{array}$ & $\begin{array}{l}\text { Social networks help to } \\
\text { broadcast, build } \\
\text { obligation and share } \\
\text { meaning, increasing } \\
\text { funding intention. }\end{array}$ & Confirm \\
\hline $\begin{array}{l}\text { Allison et al. } \\
\text { (2017) }\end{array}$ & Structural & $\begin{array}{l}\text { Social } \\
\text { network }\end{array}$ & $\begin{array}{l}\text { Reward- } \\
\text { based }\end{array}$ & $\begin{array}{l}\text { The number of times } \\
\text { the project's funding } \\
\text { page was shared on } \\
\text { Facebook }\end{array}$ & $\begin{array}{l}\text { Social networks as } \\
\text { control variables }\end{array}$ & Disconfirm \\
\hline
\end{tabular}




\begin{tabular}{|c|c|c|c|c|c|c|}
\hline $\begin{array}{l}\text { Kunz et al. } \\
\text { (2017) }\end{array}$ & Structural & $\begin{array}{l}\text { Social } \\
\text { network }\end{array}$ & $\begin{array}{l}\text { Reward- } \\
\text { based }\end{array}$ & $\begin{array}{l}\text { The number of } \\
\text { Facebook friends }\end{array}$ & $\begin{array}{l}\text { Social networks increase } \\
\text { entrepreneurs' } \\
\text { trustworthiness. }\end{array}$ & Confirm \\
\hline $\begin{array}{l}\text { Roma et al. } \\
(2017)\end{array}$ & Structural & $\begin{array}{l}\text { Social } \\
\text { network }\end{array}$ & $\begin{array}{l}\text { Reward- } \\
\text { based }\end{array}$ & $\begin{array}{l}\text { The total LinkedIn } \\
\text { connections }\end{array}$ & $\begin{array}{l}\text { Entrepreneur’s social } \\
\text { network attracts } \\
\text { professional investors. }\end{array}$ & Confirm \\
\hline $\begin{array}{l}\text { Kang et al. } \\
\text { (2017) }\end{array}$ & Structural & $\begin{array}{l}\text { Social } \\
\text { network }\end{array}$ & $\begin{array}{l}\text { Reward- } \\
\text { based }\end{array}$ & $\begin{array}{l}\text { The number of Sina } \\
\text { Weibo followers }\end{array}$ & $\begin{array}{l}\text { Advocates' social capital } \\
\text { positively associates with } \\
\text { funding performance, and } \\
\text { distance can enhance this } \\
\text { relationship. }\end{array}$ & Confirm \\
\hline $\begin{array}{l}\text { Bao and } \\
\text { Huang } \\
\text { (2017) }\end{array}$ & $\begin{array}{l}\text { Structural/ } \\
\text { relational }\end{array}$ & $\begin{array}{l}\text { Social } \\
\text { network/ } \\
\text { obligation }\end{array}$ & $\begin{array}{l}\text { Reward- } \\
\text { based }\end{array}$ & $\begin{array}{l}\text { Number of Facebook } \\
\text { friends and backing } \\
\text { projects }\end{array}$ & $\begin{array}{l}\text { Social networks help to } \\
\text { advertise; obligation leads } \\
\text { to a reciprocity } \\
\text { mechanism. }\end{array}$ & Confirm \\
\hline $\begin{array}{l}\text { Liao et al. } \\
\text { (2015) }\end{array}$ & $\begin{array}{l}\text { Structural/ } \\
\text { relational }\end{array}$ & $\begin{array}{l}\text { Social } \\
\text { networks/ } \\
\text { praise and } \\
\text { obligation }\end{array}$ & $\begin{array}{l}\text { Reward- } \\
\text { based }\end{array}$ & $\begin{array}{l}\text { Number of Facebook } \\
\text { friends, sharing of } \\
\text { the project/actions of } \\
\text { 'like' and 'support' }\end{array}$ & $\begin{array}{l}\text { Both structural and } \\
\text { relational social capital } \\
\text { positively affect } \\
\text { crowdfunding } \\
\text { performance, and this } \\
\text { relationship is moderated } \\
\text { by project types. }\end{array}$ & Confirm \\
\hline $\begin{array}{l}\text { Lin et al. } \\
\text { (2013) }\end{array}$ & Structural & $\begin{array}{l}\text { Friendship } \\
\text { networks }\end{array}$ & Lending & $\begin{array}{l}\text { Friendship hierarchy } \\
\text { from levels } 1 \text { to } 5\end{array}$ & $\begin{array}{l}\text { Friendship can mitigate } \\
\text { adverse selection and } \\
\text { information asymmetry. }\end{array}$ & Confirm \\
\hline $\begin{array}{l}\text { Chen et al. } \\
\text { (2016) }\end{array}$ & $\begin{array}{l}\text { Structural/ } \\
\text { relational }\end{array}$ & $\begin{array}{l}\text { Social } \\
\text { network/ } \\
\text { trust/identity }\end{array}$ & Lending & $\begin{array}{l}\text { The affiliated group } \\
\text { size/group leader } \\
\text { endorsement/ } \\
\text { whether group } \\
\text { members make a bid }\end{array}$ & $\begin{array}{l}\text { The greater the group } \\
\text { size, the weaker the group } \\
\text { cohesion/leader } \\
\text { endorsement increases } \\
\text { funding intention/identity } \\
\text { conveys a signal for the }\end{array}$ & 西 \\
\hline
\end{tabular}


verification of borrowers,

reducing the interest rate.

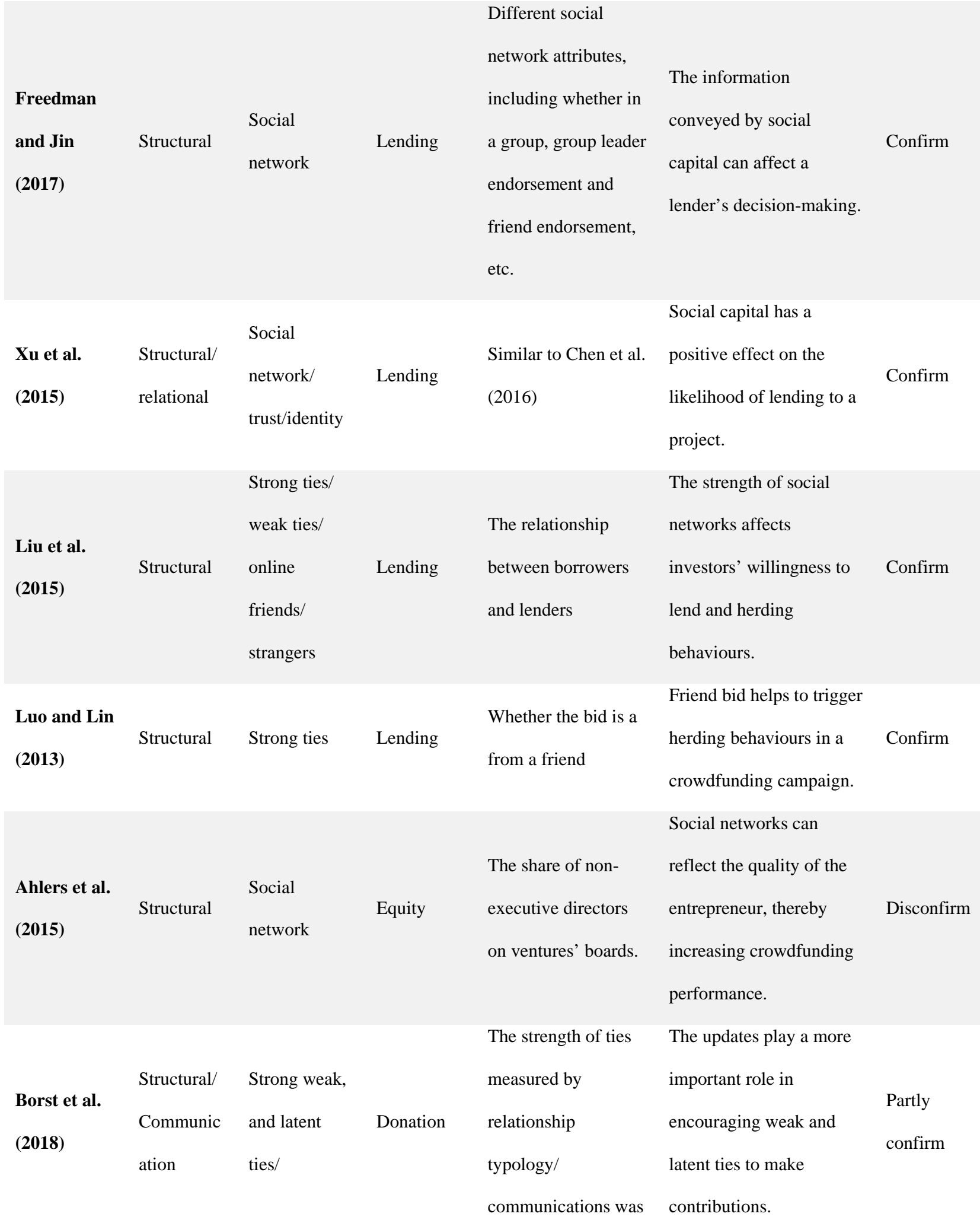


measured by

frequency of project

and social media

updates.

\begin{tabular}{|c|c|c|c|}
\hline Vismara & & & The number of \\
\hline (2016a) & Structural & Equity & LinkedIn proponents \\
\hline
\end{tabular}

The share of non-

$\begin{array}{llll}\text { Vismara } & & \text { Social } & \\ \text { (2016b) } & \text { Structural } & & \text { Equity }\end{array}$

Lukkarinen

et al. (2016)
Social

network
Equity

hidden phase and

dummy variable $=1$

if the company has

Facebook activities

The strength of the

Polzin et al.

(2018)

Structural

Strong, weak

and no ties

All types

relationship between

entrepreneurs and

investors

Successful

crowdfunding

Zheng et al.

Relational Trust

(2016)

Reward-

based

experience;

investment in others;

and entrepreneur-

sponsor interactions

Past loan activities,

Lending

Trust/

obligation

Social networks help

overcome information Confirm

asymmetry.

Social networks can

reflect the quality of the Disconfirm

entrepreneur.

Private networks attract

early funding, leading to

a high success rate. Social

Confirm

media network also

contributes to

crowdfunding success.

The strength of social

network affects investors’ Confirm

decision-making.

\section{Both entrepreneur's}

entrepreneur-sponsor

interactions and

creditworthiness have a Confirm

positive influence on

crowdfunding

performance.

The transaction history is

a substitute for Confirm

creditworthiness. 


\begin{tabular}{|c|c|c|c|c|c|c|}
\hline $\begin{array}{l}\text { Chen et al. } \\
\text { (2015) }\end{array}$ & Relational & Trust & Lending & $\begin{array}{l}\text { Survey on actual } \\
\text { lenders on PPDAI. }\end{array}$ & $\begin{array}{l}\text { Social capital can } \\
\text { enhance an investor’s } \\
\text { funding willingness by } \\
\text { increasing the trust in } \\
\text { borrowers. }\end{array}$ & Confirm \\
\hline $\begin{array}{l}\text { Greiner and } \\
\text { Wang } \\
\text { (2010) }\end{array}$ & Relational & Trust & Lending & $\begin{array}{l}\text { Group membership, } \\
\text { group leader reward } \\
\text { rate and group } \\
\text { member } \\
\text { endorsement }\end{array}$ & $\begin{array}{l}\text { Trust behaviours are a } \\
\text { peripheral route to } \\
\text { increase crowdfunding } \\
\text { performance in an ELM } \\
\text { model, }\end{array}$ & Confirm \\
\hline $\begin{array}{l}\text { Lee and Lee } \\
\text { (2012) }\end{array}$ & Relational & $\begin{array}{l}\text { Trust/ } \\
\text { communicati } \\
\text { on }\end{array}$ & Lending & $\begin{array}{l}\text { Identity verification/ } \\
\text { number of Q\&As }\end{array}$ & $\begin{array}{l}\text { Both identity verification } \\
\text { and the number of Q\&As } \\
\text { can attract more bids. }\end{array}$ & Confirm \\
\hline $\begin{array}{l}\text { Zhao et al. } \\
\text { (2017) }\end{array}$ & $\begin{array}{l}\text { Relational/ } \\
\text { cognitive }\end{array}$ & $\begin{array}{l}\text { Trust/ } \\
\text { commitment/ } \\
\text { shared value }\end{array}$ & $\begin{array}{l}\text { Reward- } \\
\text { based }\end{array}$ & $\begin{array}{l}\text { Survey adapted from } \\
\text { previous research }\end{array}$ & $\begin{array}{l}\text { Trust and commitment } \\
\text { enhance funding intention } \\
\text { by reducing perceived } \\
\text { risk; shared value } \\
\text { enhances trust and } \\
\text { commitment. }\end{array}$ & 西 \\
\hline $\begin{array}{l}\text { Cholakova } \\
\text { and } \\
\text { Clarysse } \\
\text { (2015) }\end{array}$ & 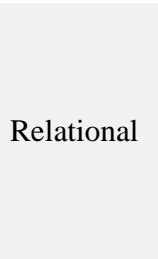 & Trust & $\begin{array}{l}\text { Reward- } \\
\text { based }\end{array}$ & $\begin{array}{l}\text { Question about 'trust } \\
\text { of use of funds' }\end{array}$ & $\begin{array}{l}\text { Trust plays a more } \\
\text { important role in reward } \\
\text { crowdfunding than } \\
\text { financial motives. }\end{array}$ & $\begin{array}{l}\text { Partially } \\
\text { Confirm }\end{array}$ \\
\hline $\begin{array}{l}\text { Kang et al. } \\
\text { (2016) }\end{array}$ & Relational & Trust & Equity & $\begin{array}{l}\text { Two questions on } \\
\text { calculus trust and } \\
\text { three questions on } \\
\text { relational trust }\end{array}$ & $\begin{array}{l}\text { Both relationship trust } \\
\text { and calculus trust mediate } \\
\text { the effect of social } \\
\text { interaction ties, network } \\
\text { externality, perceived } \\
\text { accreditation and third- } \\
\text { party seal, etc., on } \\
\text { funding motivation. }\end{array}$ & Confirm \\
\hline
\end{tabular}




\begin{tabular}{|c|c|c|c|c|c|c|}
\hline Rau (2017) & Relational & Trust & All types & $\begin{array}{l}\text { World Values } \\
\text { Survey on trust } \\
\text { towards strangers }\end{array}$ & $\begin{array}{l}\text { Trust has a positive effect } \\
\text { on national crowdfunding } \\
\text { volume. }\end{array}$ & Confirm \\
\hline $\begin{array}{l}\text { Butticè et al. } \\
(2017)\end{array}$ & Relational & Obligation & $\begin{array}{l}\text { Reward- } \\
\text { based }\end{array}$ & $\begin{array}{l}\text { The number of } \\
\text { comments which the } \\
\text { crowdfunders had } \\
\text { posted on backed } \\
\text { projects }\end{array}$ & $\begin{array}{l}\text { The social capital from } \\
\text { backing activity has a } \\
\text { positive effect on } \\
\text { crowdfunding success. }\end{array}$ & Confirm \\
\hline $\begin{array}{l}\text { Skirnevskiy } \\
\text { et al. (2017) }\end{array}$ & Relational & Obligation & $\begin{array}{l}\text { Reward- } \\
\text { based }\end{array}$ & $\begin{array}{l}\text { The number of } \\
\text { projects which } \\
\text { entrepreneurs have } \\
\text { created on the } \\
\text { platform }\end{array}$ & $\begin{array}{l}\text { The social capital affects } \\
\text { crowdfunding } \\
\text { performance by the } \\
\text { mediation of early } \\
\text { backers. }\end{array}$ & Confirm \\
\hline $\begin{array}{l}\text { André et al. } \\
\text { (2017) }\end{array}$ & Relational & Reciprocity & $\begin{array}{l}\text { Reward- } \\
\text { based }\end{array}$ & $\begin{array}{l}\text { The proportion of } \\
\text { pledges of which } \\
\text { amount is higher } \\
\text { than that of reward }\end{array}$ & $\begin{array}{l}\text { Reciprocal giving has a } \\
\text { positive effect on } \\
\text { crowdfunding } \\
\text { performance. }\end{array}$ & Confirm \\
\hline $\begin{array}{l}\text { Zvilichovsky } \\
\text { et al. (2015) }\end{array}$ & Relational & Reciprocity & $\begin{array}{l}\text { Reward- } \\
\text { based }\end{array}$ & $\begin{array}{l}\text { The number of } \\
\text { backers who are } \\
\text { supported by the } \\
\text { owner }\end{array}$ & $\begin{array}{l}\text { Both direct reciprocity } \\
\text { and indirect reciprocity } \\
\text { have a positive impact on } \\
\text { crowdfunding success. }\end{array}$ & Confirm \\
\hline $\begin{array}{l}\text { Kromidha } \\
\text { and Robson } \\
\text { (2016) }\end{array}$ & 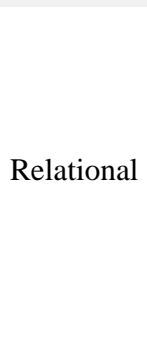 & $\begin{array}{l}\text { Identity/ } \\
\text { Communicati } \\
\text { on }\end{array}$ & $\begin{array}{l}\text { Reward- } \\
\text { based }\end{array}$ & $\begin{array}{l}\text { The number of } \\
\text { project shares by } \\
\text { supporters/number of } \\
\text { comments and } \\
\text { updates }\end{array}$ & $\begin{array}{l}\text { Both identity and } \\
\text { communication positively } \\
\text { associate with the success } \\
\text { rate. }\end{array}$ & 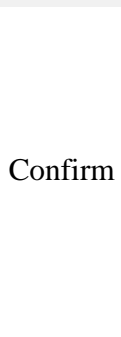 \\
\hline $\begin{array}{l}\text { Allison et al. } \\
\text { (2017) }\end{array}$ & Relational & Identity & $\begin{array}{l}\text { Reward- } \\
\text { based }\end{array}$ & $\begin{array}{l}\text { Dummy variable = } 1 \\
\text { if the entrepreneurs } \\
\text { use the term 'we' or } \\
\text { 'together' }\end{array}$ & $\begin{array}{l}\text { Group identity positively } \\
\text { affects crowdfunding } \\
\text { performance by calling } \\
\text { for commitments and } \\
\text { influencing narrative } \\
\text { effectiveness. }\end{array}$ & $x^{2}$ \\
\hline
\end{tabular}




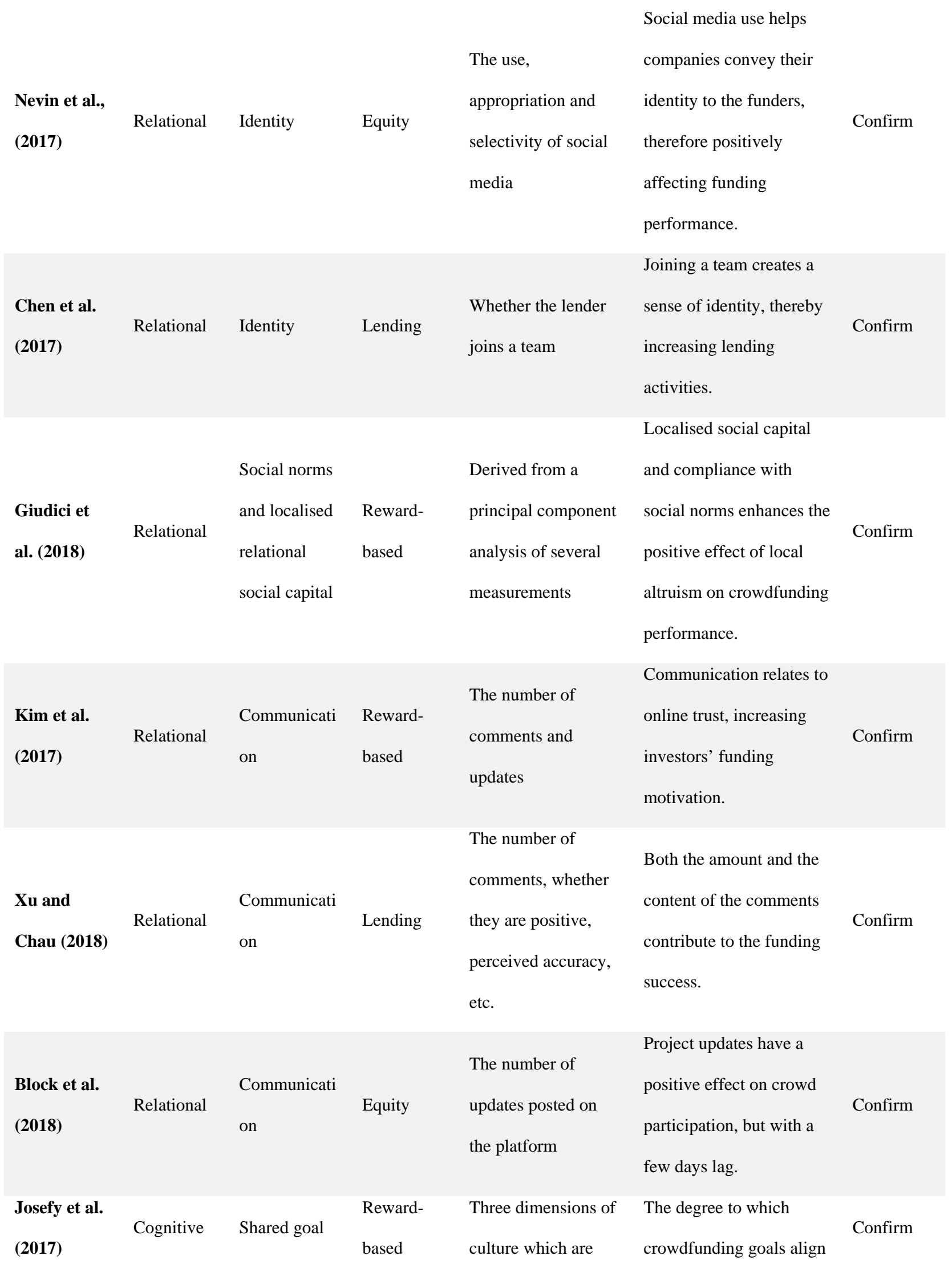




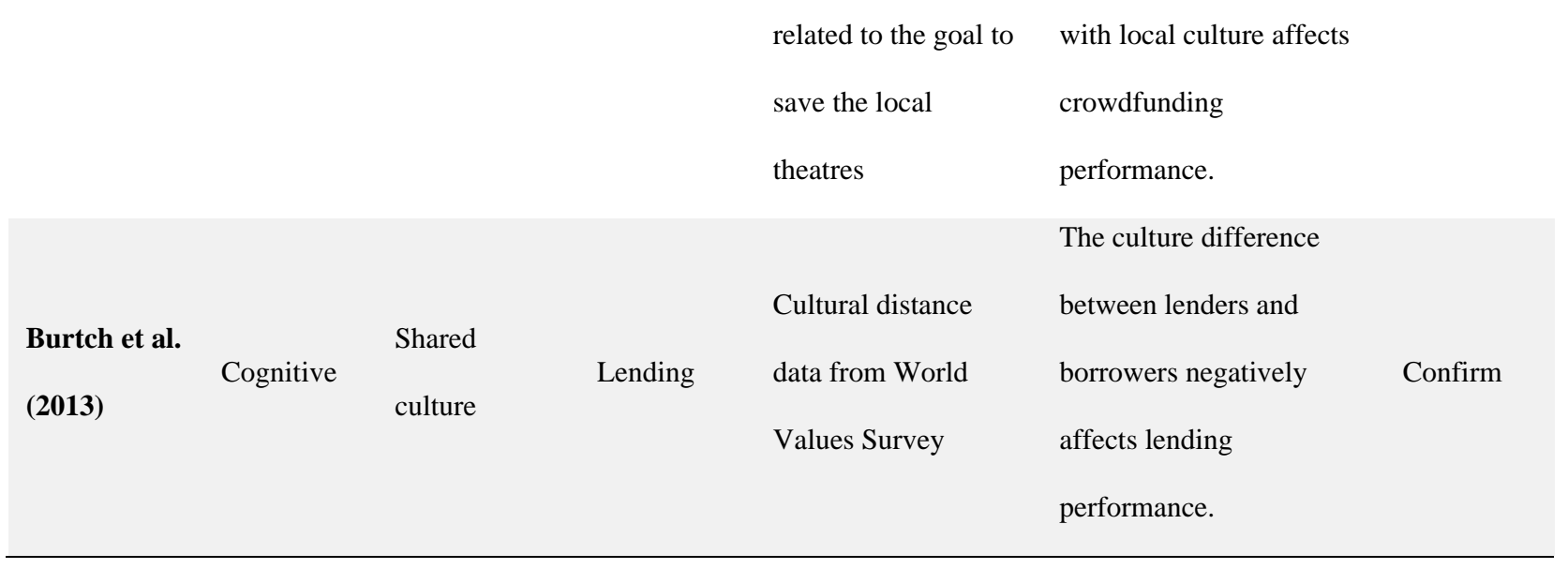

\section{References}

Agrawal, A., Catalini, C. and Goldfarb, A. (2015). Crowdfunding: Geography, social networks, and the timing of investment decisions, Journal of Economics \& Management Strategy, 24, pp. 253-274.

Agrawal, A., Catalini, C. and Goldfarb, A. (2016). Are syndicates the killer app of equity crowdfunding?, California Management Review, 58, pp. 111-124.

Ahlers, G. K., Cumming, D., Günther, C. and Schweizer, D. (2015). Signaling in equity crowdfunding, Entrepreneurship Theory and Practice, 39, pp. 955-980.

Ai, W., Chen, R., Chen, Y., Mei, Q. and Phillips, W. (2016). Recommending teams promotes prosocial lending in online microfinance, Proceedings of the National Academy of Sciences of the United States of America, 113, pp. 14944-14948. DOI: 10.1073/pnas.1606085113.

Allison, T. H., Davis, B. C., Short, J. C. and Webb, J. W. (2015). Crowdfunding in a prosocial microlending environment: Examining the role of intrinsic versus extrinsic cues, Entrepreneurship Theory and Practice, 39, pp. 53-73.

Allison, T. H., Davis, B. C., Webb, J. W. and Short, J. C. (2017). Persuasion in crowdfunding: An elaboration likelihood model of crowdfunding performance, Journal of Business Venturing, 32, pp. 707-725.

André, K., Bureau, S., Gautier, A. and Rubel, O. (2017). Beyond the opposition between altruism and self-interest: Reciprocal giving in reward-based crowdfunding, Journal of Business Ethics, 146, pp. 313-332.

Anglin, A. H., Short, J. C., Drover, W., Stevenson, R. M., McKenny, A. F. and Allison, T. H. (2018). The power of positivity? The influence of positive psychological capital language on crowdfunding performance, Journal of Business Venturing. 
Bao, Z. and Huang, T. (2017). External supports in reward-based crowdfunding campaigns: A comparative study focused on cultural and creative projects, Online Information Review, 41, pp. 626-642. DOI: 10.1108/OIR-10-2016-0292.

Bartsch, V., Ebers, M. and Maurer, I. (2013). Learning in project-based organizations: The role of project teams' social capital for overcoming barriers to learning, International Journal of Project Management, 31, pp. 239-251.

Belleflamme, P., Lambert, T. and Schwienbacher, A. (2014). Crowdfunding: Tapping the right crowd, Journal of Business Venturing, 29, pp. 585-609.

Belleflamme, P., Omrani, N. and Peitz, M. (2015). The economics of crowdfunding platforms, Information Economics and Policy, 33, pp. 11-28. DOI: 10.1016/j.infoecopol.2015.08.003.

Bercovitz, J. and Feldman, M. (2011). The mechanisms of collaboration in inventive teams: Composition, social networks, and geography, Research Policy, 40, pp. 81-93.

Block, J. H., Colombo, M. G., Cumming, D. J. and Vismara, S. (2018). New players in entrepreneurial finance and why they are there, Small Business Economics, 50, pp. 239250.

Block, J., Hornuf, L. and Moritz, A. (2018). Which updates during an equity crowdfunding campaign increase crowd participation?, Small Business Economics, 50, pp. 3-27.

Borgatti, S. P., Brass, D. J. and Halgin, D. S. (2014). Social network research: Confusions, criticisms, and controversies. InContemporary perspectives on organizational social networks. Emerald Group Publishing Limited, pp. 1-29.

Borst, I., Moser, C. and Ferguson, J. (2018). From friendfunding to crowdfunding: Relevance of relationships, social media, and platform activities to crowdfunding performance, New Media \& Society, 20, pp. 1396-1414.

Bottazzi, L., Da Rin, M. and Hellmann, T. F. (2011). The importance of trust for investment: Evidence from venture capital. National Bureau of Economic Research.

Bouncken, R. B., Komorek, M. and Kraus, S. (2015). Crowdfunding: The current state of research, The International Business \& Economics Research Journal (Online), 14, pp. 407.

Bruton, G., Khavul, S., Siegel, D. and Wright, M. (2015). New financial alternatives in seeding entrepreneurship: Microfinance, crowdfunding, and peer-to-peer innovations, Entrepreneurship Theory and Practice, 39, pp. 9-26.

Burtch, G., Ghose, A. and Wattal, S. (2013). Cultural differences and geography as determinants of online pro-social lending. 
Burtch, G., Ghose, A. and Wattal, S. (2016). Secret Admirers: An Empirical Examination of Information Hiding and Contribution Dynamics in Online Crowdfunding, Information Systems Research, 27, pp. 478-496. DOI: 10.1287/isre.2016.0642.

Butler Jr, J. K. and Cantrell, R. S. (1984). A behavioral decision theory approach to modeling dyadic trust in superiors and subordinates, Psychological Reports, 55, pp. 19-28.

Butticè, V., Colombo, M. G. and Wright, M. (2017). Serial crowdfunding, social capital, and project success, Entrepreneurship Theory and Practice, 41, pp. 183-207.

Chang, H. H. and Chuang, S.-S. (2011). Social capital and individual motivations on knowledge sharing: Participant involvement as a moderator, Information \& Management, 48, pp. 918.

Chang, T.-S. and Hsiao, W.-H. (2013). Factors influencing intentions to use social recommender systems: A social exchange perspective, Cyberpsychology, Behavior, and Social Networking, 16, pp. 357-363.

Chen, D., Lai, F. and Lin, Z. (2014). A trust model for online peer-to-peer lending: a lender's perspective, Information Technology and Management, 15, pp. 239-254. DOI: 10.1007/s10799-014-0187-z.

Chen, D., Lou, H. and Van Slyke, C. (2015). Toward an Understanding of Online Lending Intentions: Evidence from a Survey in China, Communications of the Association for Information Systems, 36, pp. 317-336.

Chen, R., Chen, Y., Liu, Y. and Mei, Q. (2017). Does team competition increase pro-social lending? Evidence from online microfinance, Games and Economic Behavior, 101, pp. 311-333. DOI: 10.1016/j.geb.2015.02.001.

Chen, X., Zhou, L. and Wan, D. (2016). Group social capital and lending outcomes in the financial credit market: An empirical study of online peer-to-peer lending, Electronic Commerce Research and Applications, 15, pp. 1-13.

Chiu, C.-M., Hsu, M.-H. and Wang, E. T. (2006). Understanding knowledge sharing in virtual communities: An integration of social capital and social cognitive theories, Decision Support Systems, 42, pp. 1872-1888.

Cho, M. and Kim, G. (2017). A cross-cultural comparative analysis of crowdfunding projects in the United States and South Korea, Computers in Human Behavior, 72, pp. 312-320.

Cholakova, M. and Clarysse, B. (2015). Does the possibility to make equity investments in crowdfunding projects crowd out reward-based investments?, Entrepreneurship Theory and Practice, 39, pp. 145-172.

Chow, W. S. and Chan, L. S. (2008). Social network, social trust and shared goals in organizational knowledge sharing, Information \& Management, 45, pp. 458-465. 
Cohen, D., Prusak, L. and Prusak, L. (2001). In good company: How social capital makes organizations work. Vol. 15. Harvard Business School Press Boston, MA.

Colombo, M. G., Franzoni, C. and Rossi-Lamastra, C. (2015). Internal social capital and the attraction of early contributions in crowdfunding, Entrepreneurship Theory and Practice, 39, pp. 75-100.

Connelly, B. L., Crook, T. R., Combs, J. G., Ketchen, D. J. and Aguinis, H. (2018). Competence- and Integrity-Based Trust in Interorganizational Relationships: Which Matters More?, Journal of Management, 44, pp. 919-945. DOI: 10.1177/0149206315596813.

Davidson, R. and Poor, N. (2016). Factors for success in repeat crowdfunding: why sugar daddies are only good for Bar-Mitzvahs, Information Communication \& Society, 19, pp. 127-139. DOI: 10.1080/1369118X.2015.1093533.

Drover, W., Busenitz, L., Matusik, S., Townsend, D., Anglin, A. and Dushnitsky, G. (2017). A review and road map of entrepreneurial equity financing research: venture capital, corporate venture capital, angel investment, crowdfunding, and accelerators, Journal of Management, 43, pp. 1820-1853.

Du, J., Guariglia, A. and Newman, A. (2015). Do Social Capital Building Strategies Influence the Financing Behavior of Chinese Private Small and Medium-Sized Enterprises?, Entrepreneurship Theory and Practice, 39, pp. 601-631.

Ellison, N. B., Steinfield, C. and Lampe, C. (2007). The Benefits of Facebook "Friends:” Social Capital and College Students' Use of Online Social Network Sites, Journal of ComputerMediated Communication, 12, pp. 1143-1168. DOI: 10.1111/j.1083-6101.2007.00367.x.

Ellison, N. B., Steinfield, C. and Lampe, C. (2011). Connection strategies: Social capital implications of Facebook-enabled communication practices, New Media \& Society, 13, pp. 873-892. DOI: 10.1177/1461444810385389.

Estrin, S., Mickiewicz, T. and Stephan, U. (2013). Entrepreneurship, social capital, and institutions: Social and commercial entrepreneurship across nations, Entrepreneurship Theory and Practice, 37, pp. 479-504.

Feller, J., Gleasure, R. and Treacy, S. (2017). Information sharing and user behavior in internetenabled peer-to-peer lending systems: an empirical study, Journal of Information Technology, 32, pp. 127-146.

Fisch, C. and Block, J. (2018). Six tips for your (systematic) literature review in business and management research. Springer.

Freedman, S. and Jin, G. Z. (2017). The information value of online social networks: lessons from peer-to-peer lending, International Journal of Industrial Organization, 51, pp. 185222. 
Gerber, E. M. and Hui, J. (2013). Crowdfunding: Motivations and deterrents for participation, ACM Transactions on Computer-Human Interaction (TOCHI), 20, pp. 34.

Gerber, E. M., Hui, J. S. and Kuo, P.-Y. (2012). Crowdfunding: Why people are motivated to post and fund projects on crowdfunding platforms. InProceedings of the International Workshop on Design, Influence, and Social Technologies: Techniques, Impacts and Ethics.2,.

Giudici, G., Guerini, M. and Rossi Lamastra, C. (2013). Why crowdfunding projects can succeed: the role of proponents' individual and territorial social capital.

Gleasure, R. and Feller, J. (2016). A Rift in the Ground: Theorizing the evolution of anchor values in crowdfunding communities through the oculus rift case study, Journal of the Association for Information Systems, 17, pp. 708.

Gleasure, R. and Morgan, L. (2018). The pastoral crowd: Exploring self-hosted crowdfunding using activity theory and social capital, Information Systems Journal, 28, pp. 489-515.

Greiner, M. E. and Wang, H. (2010). Building Consumer-to-Consumer Trust in E-Finance Marketplaces: An Empirical Analysis, International Journal of Electronic Commerce, 15, pp. 105-136. DOI: 10.2753/JEC1086-4415150204.

Hoffman, J. J., Hoelscher, M. L. and Sherif, K. (2005). Social capital, knowledge management, and sustained superior performance, Journal of Knowledge Management, 9, pp. 93-100.

Hopkins, N. (2011). Religion and social capital: Identity matters, Journal of Community \& Applied Social Psychology, 21, pp. 528-540.

Hui, J. S., Greenberg, M. D. and Gerber, E. M. (2014). Understanding the role of community in crowdfunding work. InProceedings of the 17th ACM conference on Computer supported cooperative work \& social computing. ACM, pp. 62-74.

Huysman, M. and De Wit, D. (2004). Practices of managing knowledge sharing: towards a second wave of knowledge management, Knowledge and Process Management, 11, pp. 81-92.

Inkpen, A. C. and Tsang, E. W. (2005). Social capital, networks, and knowledge transfer, Academy of Management Review, 30, pp. 146-165.

Jih, W.-J. K., Lee, S.-F. and Tsai, Y.-C. (2007). Effects of service quality and shared value on trust and commitment: An empirical study of 3Cs product customers in Taiwan, International Journal of Business Studies: A Publication of the Faculty of Business Administration, Edith Cowan University, 15, pp. 83.

Josefy, M., Dean, T. J., Albert, L. S. and Fitza, M. A. (2017). The Role of Community in Crowdfunding Success: Evidence on Cultural Attributes in Funding Campaigns to "Save the Local Theater”, Entrepreneurship Theory and Practice, 41, pp. 161-182. 
Kang, L., Jiang, Q. and Tan, C.-H. (2017). Remarkable advocates: An investigation of geographic distance and social capital for crowdfunding, Information \& Management, 54, pp. 336-348. DOI: 10.1016/j.im.2016.09.001.

Kang, M., Gao, Y., Wang, T. and Zheng, H. (2016). Understanding the determinants of funders' investment intentions on crowdfunding platforms: A trust-based perspective, Industrial Management \& Data Systems, 116, pp. 1800-1819.

Kromidha, E. and Robson, P. (2016). Social identity and signalling success factors in online crowdfunding, Entrepreneurship \& Regional Development, 28, pp. 605-629.

Kshetri, N. (2015). Success of crowd-based online technology in fundraising: An institutional perspective, Journal of International Management, 21, pp. 100-116.

Kshetri, N. (2017). Informal Institutions and Internet-based Equity Crowdfunding, Journal of International Management.

Kunz, M. M., Bretschneider, U., Erler, M. and Leimeister, J. M. (2017). An empirical investigation of signaling in reward-based crowdfunding, Electronic Commerce Research, 17, pp. 425-461.

Lee, E. and Lee, B. (2012). Herding behavior in online P2P lending: An empirical investigation, Electronic Commerce Research and Applications, 11, pp. 495-503. DOI: 10.1016/j.elerap.2012.02.001.

Leyden, D. P., Link, A. N. and Siegel, D. S. (2014). A theoretical analysis of the role of social networks in entrepreneurship, Research Policy, 43, pp. 1157-1163.

Liao, C., Zhu, Y. and Liao, X. (2015). The Role of Internal and External Social Capital in Crowdfunding: Evidence from China, Revista De Cercetare Si Interventie Sociala, 49, pp. 187-204.

Lin, M., Prabhala, N. R. and Viswanathan, S. (2013). Judging borrowers by the company they keep: Friendship networks and information asymmetry in online peer-to-peer lending, Management Science, 59, pp. 17-35.

Liu, D., Brass, D. J., Lu, Y. and Chen, D. (2015). Friendships in Online Peer-to-Peer Lending: Pipes, Prisms, and Relational Herding, Mis Quarterly, 39, pp. 729- +. DOI: 10.25300/MISQ/2015/39.3.11.

Lukkarinen, A., Teich, J. E., Wallenius, H. and Wallenius, J. (2016). Success drivers of online equity crowdfunding campaigns, Decision Support Systems, 87, pp. 26-38.

Luo, B. and Lin, Z. (2013). A decision tree model for herd behavior and empirical evidence from the online P2P lending market, Information Systems and E-Business Management, 11, pp. 141-160. DOI: 10.1007/s10257-011-0182-4. 
MacMillan, K., Money, K., Money, A. and Downing, S. (2005). Relationship marketing in the not-for-profit sector: an extension and application of the commitment-trust theory, Journal of Business Research, 58, pp. 806-818.

McKenny, A. F., Allison, T. H., Ketchen, D. J., Short, J. C. and Ireland, R. D. (2017). How Should Crowdfunding Research Evolve? A Survey of the Entrepreneurship Theory and Practice Editorial Board, Entrepreneurship Theory and Practice, 41, pp. 291-304.

Mochkabadi, K. and Volkmann, C. K. (2018). Equity crowdfunding: a systematic review of the literature, Small Business Economics. DOI: 10.1007/s11187-018-0081-x.

Mohammadi, A. and Shafi, K. (2018). Gender differences in the contribution patterns of equitycrowdfunding investors, Small Business Economics, 50, pp. 275-287.

Mollick, E. (2014). The dynamics of crowdfunding: An exploratory study, Journal of Business Venturing, 29, pp. 1-16.

Morgan, R. M. and Hunt, S. D. (1994). The commitment-trust theory of relationship marketing, The Journal of Marketing, pp. 20-38.

Nahapiet, J. and Ghoshal, S. (2000). Social capital, intellectual capital, and the organizational advantage. InKnowledge and social capital. Elsevier, pp. 119-157.

Nevin, S., Gleasure, R., O’Reilly, P., Feller, J., Li, S. and Cristoforo, J. (2017). Social Identity and Social Media Activities in Equity Crowdfunding. InProceedings of the 13th International Symposium on Open Collaboration. ACM, pp. 11.

Nguyen, D. H., de Leeuw, S. and Dullaert, W. E. H. (2018). Consumer Behaviour and Order Fulfilment in Online Retailing: A Systematic Review: Order Fulfilment in Online Retailing, International Journal of Management Reviews, 20, pp. 255-276. DOI: 10.1111/ijmr.12129.

Ordanini, A., Miceli, L., Pizzetti, M. and Parasuraman, A. (2011). Crowd-funding: transforming customers into investors through innovative service platforms, Journal of Service Management, 22, pp. 443-470.

Pan, X., Han, C. S., Dauber, K. and Law, K. H. (2007). A multi-agent based framework for the simulation of human and social behaviors during emergency evacuations, Ai \& Society, 22, pp. 113-132.

Payne, G. T., Moore, C. B., Griffis, S. E. and Autry, C. W. (2011). Multilevel challenges and opportunities in social capital research, Journal of Management, 37, pp. 491-520.

Polzin, F., Toxopeus, H. and Stam, E. (2018). The wisdom of the crowd in funding: information heterogeneity and social networks of crowdfunders, Small Business Economics, 50, pp. 251-273. 
Putnam, R. D. (2000). Bowling alone: America’s declining social capital. InCulture and politics. Springer, pp. 223-234.

Rau, P. R. (2017). Law, trust, and the development of crowdfunding.

Reiche, B. S., Harzing, A.-W. and Pudelko, M. (2015). Why and how does shared language affect subsidiary knowledge inflows? A social identity perspective, Journal of International Business Studies, 46, pp. 528-551.

Requena, F. (2003). Social capital, satisfaction and quality of life in the workplace, Social Indicators Research, 61, pp. 331-360.

Roma, P., Petruzzelli, A. M. and Perrone, G. (2017). From the crowd to the market: The role of reward-based crowdfunding performance in attracting professional investors, Research Policy, 46, pp. 1606-1628. DOI: 10.1016/j.respol.2017.07.012.

Saxton, G. D. and Wang, L. (2014). The social network effect: The determinants of giving through social media, Nonprofit and Voluntary Sector Quarterly, 43, pp. 850-868.

Schultz, P. W., Nolan, J. M., Cialdini, R. B., Goldstein, N. J. and Griskevicius, V. (2007). The constructive, destructive, and reconstructive power of social norms, Psychological Science, 18, pp. 429-434.

Shamir, B., House, R. J. and Arthur, M. B. (1993). The motivational effects of charismatic leadership: A self-concept based theory, Organization Science, 4, pp. 577-594.

Shane, S. and Cable, D. (2002). Network ties, reputation, and the financing of new ventures, Management Science, 48, pp. 364-381.

Short, J. C., Ketchen, D. J., McKenny, A. F., Allison, T. H. and Ireland, R. D. (2017). Research on crowdfunding: Reviewing the (very recent) past and celebrating the present, Entrepreneurship Theory and Practice, 41, pp. 149-160.

Sitkin, S. B. and Roth, N. L. (1993). Explaining the limited effectiveness of legalistic “remedies” for trust/distrust, Organization Science, 4, pp. 367-392.

Skirnevskiy, V., Bendig, D. and Brettel, M. (2017). The influence of internal social capital on serial creators' success in crowdfunding, Entrepreneurship Theory and Practice, 41, pp. 209-236.

Sorenson, O. and Stuart, T. E. (2001). Syndication networks and the spatial distribution of venture capital investments, American Journal of Sociology, 106, pp. 1546-1588.

Tsai, W. and Ghoshal, S. (1998). Social capital and value creation: The role of intrafirm networks, Academy of Management Journal, 41, pp. 464-476. 
Valenzuela, S., Park, N. and Kee, K. F. (2009). Is there social capital in a social network site?: Facebook use and college students’ life satisfaction, trust, and participation, Journal of Computer-Mediated Communication, 14, pp. 875-901.

Villena, V. H., Revilla, E. and Choi, T. Y. (2011). The dark side of buyer-supplier relationships: A social capital perspective, Journal of Operations Management, 29, pp. 561-576.

Vismara, S. (2016a). Equity retention and social network theory in equity crowdfunding, Small Business Economics, 46, pp. 579-590.

Vismara, S. (2016b). Information cascades among investors in equity crowdfunding, Entrepreneurship Theory and Practice.

Wasko, M. M. and Faraj, S. (2005). Why should I share? Examining social capital and knowledge contribution in electronic networks of practice, MIS Quarterly, pp. 35-57.

Wu, J., Chiclana, F., Fujita, H. and Herrera-Viedma, E. (2017). A visual interaction consensus model for social network group decision making with trust propagation, KnowledgeBased Systems, 122, pp. 39-50.

Xu, J. J. and Chau, M. (2018). Cheap Talk? The Impact of Lender-Borrower Communication on Peer-to-Peer Lending Outcomes, Journal of Management Information Systems, 35, pp. 53-85. DOI: 10.1080/07421222.2018.1440776.

Xu, Y., Luo, C., Chen, D. and Zheng, H. (2015). What Influences the Market Outcome of Online P2P Lending Marketplace? A Cross-Country Analysis, Journal of Global Information Management, 23, pp. 23-40. DOI: 10.4018/JGIM.2015070102.

Yum, H., Lee, B. and Chae, M. (2012). From the wisdom of crowds to my own judgment in microfinance through online peer-to-peer lending platforms, Electronic Commerce Research and Applications, 11, pp. 469-483. DOI: 10.1016/j.elerap.2012.05.003.

Zhao, Q., Chen, C.-D., Wang, J.-L. and Chen, P.-C. (2017). Determinants of backers' funding intention in crowdfunding: Social exchange theory and regulatory focus, Telematics and Informatics, 34, pp. 370-384.

Zheng, H., Hung, J.-L., Qi, Z. and Xu, B. (2016). The role of trust management in reward-based crowdfunding, Online Information Review, 40, pp. 97-118.

Zheng, H., Li, D., Wu, J. and Xu, Y. (2014). The role of multidimensional social capital in crowdfunding: A comparative study in China and US, Information \& Management, 51, pp. 488-496.

Zvilichovsky, D., Inbar, Y. and Barzilay, O. (2015). Playing both sides of the market: Success and reciprocity on crowdfunding platforms. 